التمكين الاقتصادي والاجتماعي للمر أة المعيلة فى ريف محافظة أسيوط

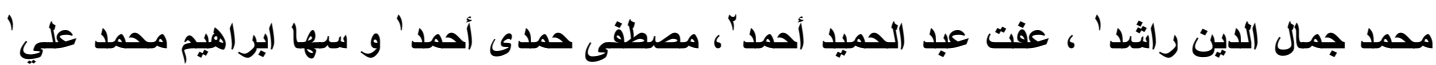

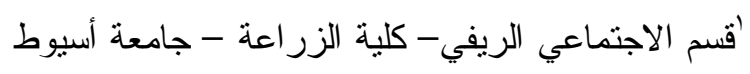

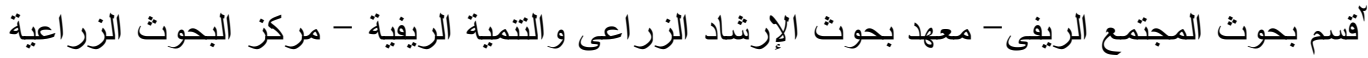

Received on: 29/3/2017

Accepted for publication on: 2/4/2017

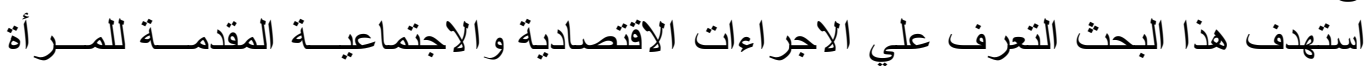

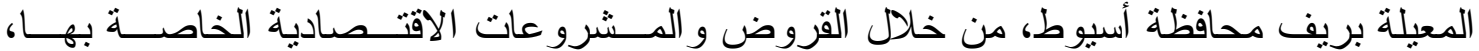

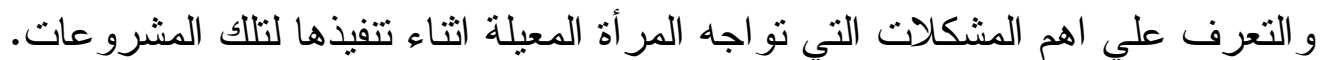

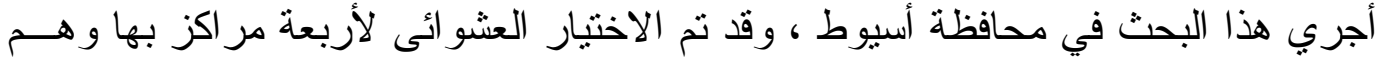

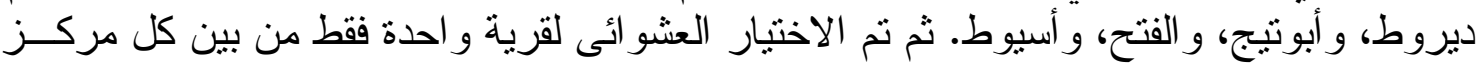
من المر اكز الأربعة المختارة.

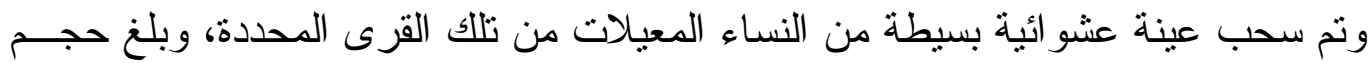

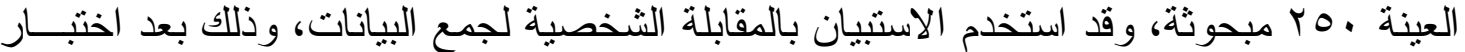

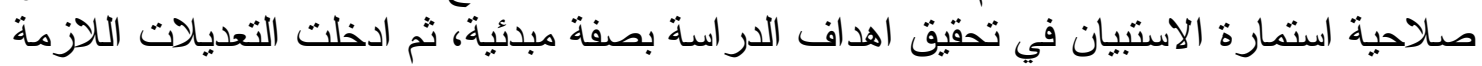

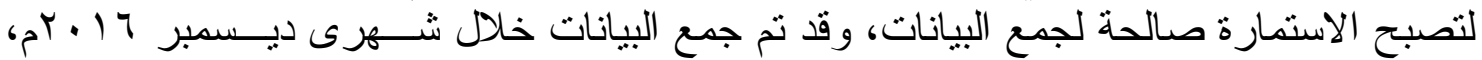

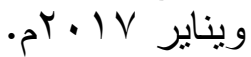

وقد استخدم في تحليل البيانات التكر ار ات و النسب المئوية. وكان من اهم النتــائج إرتنــــاع

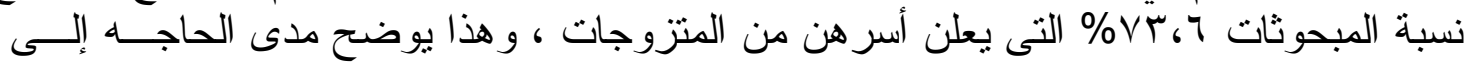

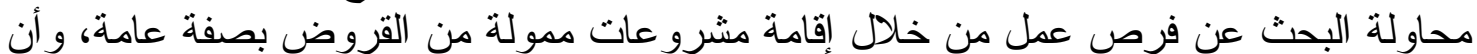

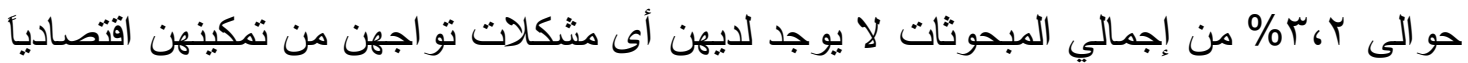

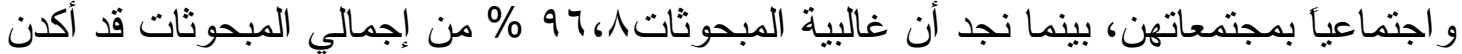
على وجود مشكلات تو اجهن فى تمكينهن اقتصادياً و اجتماعياً بمجتمعاتهن.

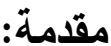

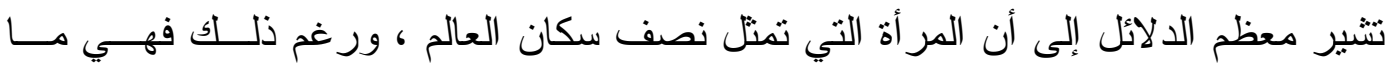

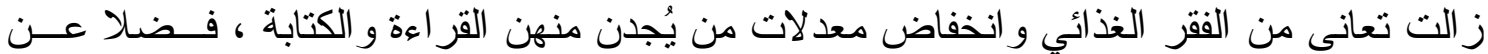

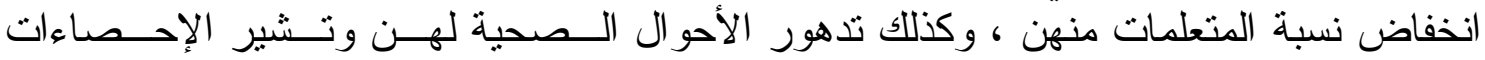

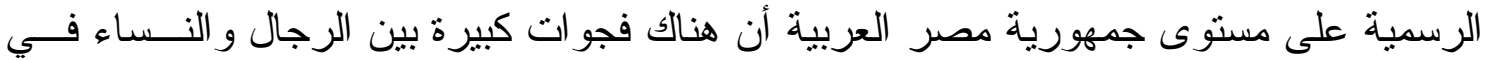

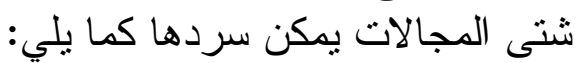

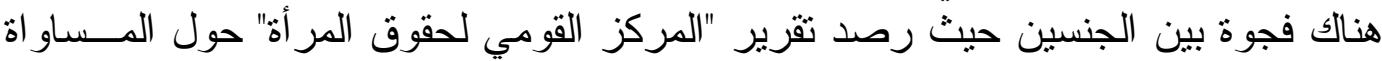

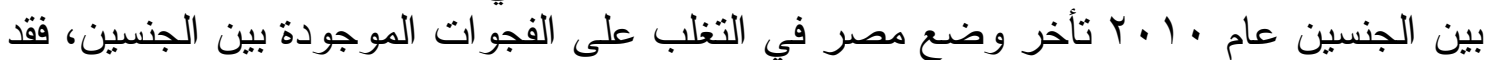

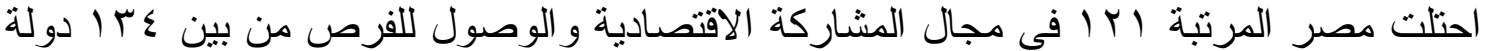

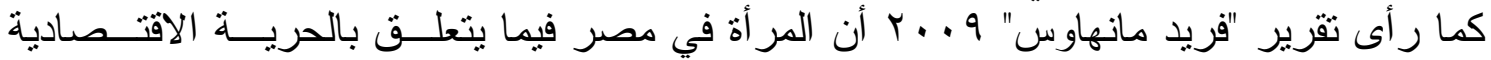

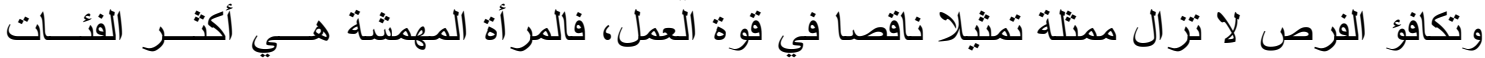

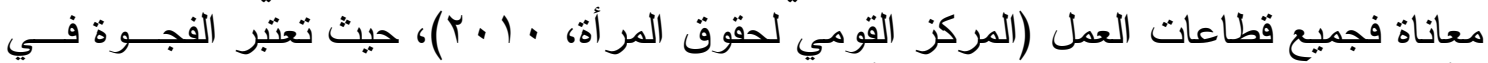

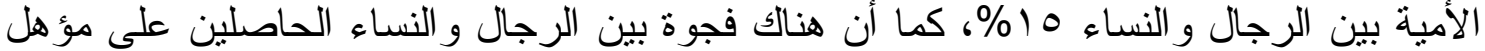

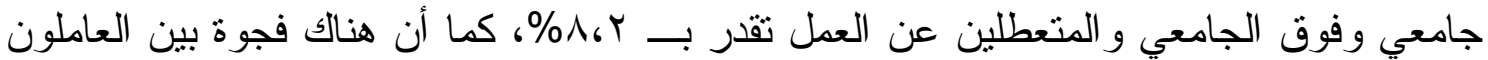

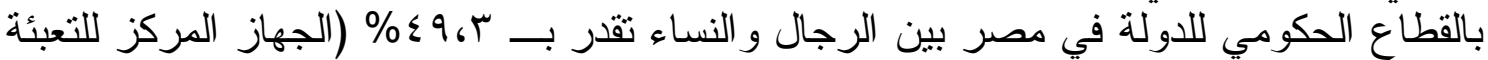

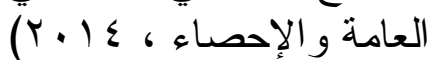

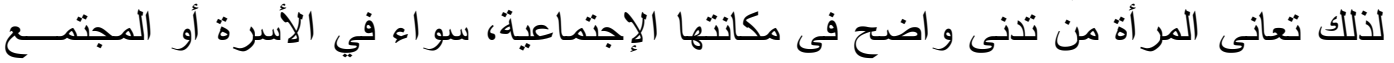

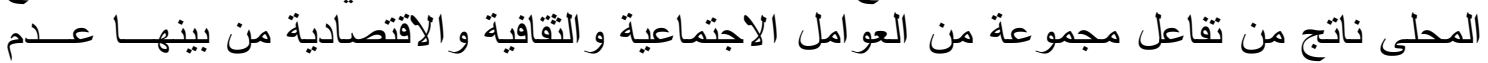




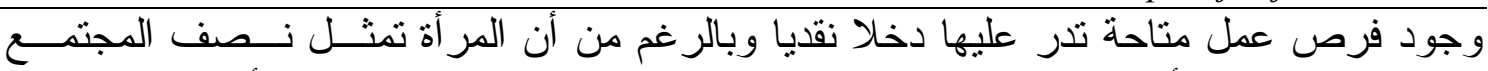

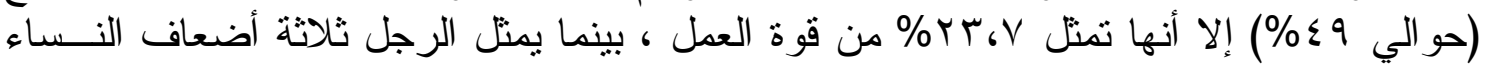

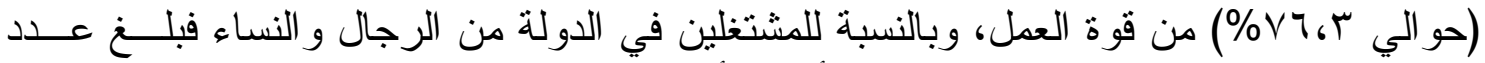

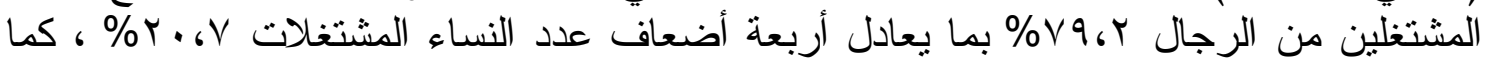

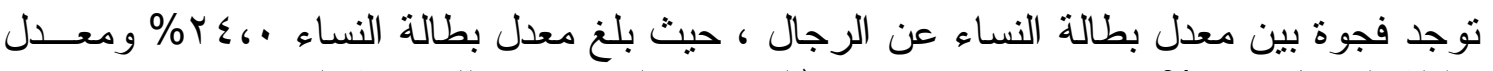

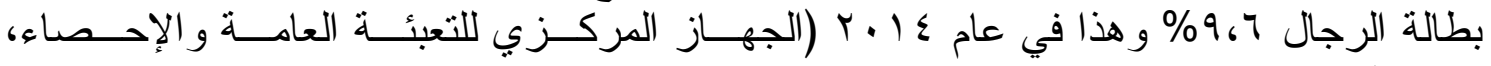
$\cdot(r \cdot) \varepsilon$

مما سبق يمكن القول أن المر أة بصفة عامة تشكل قدر كبير من إجمالي القــوى البــشرية

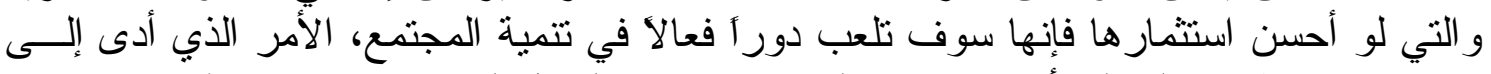

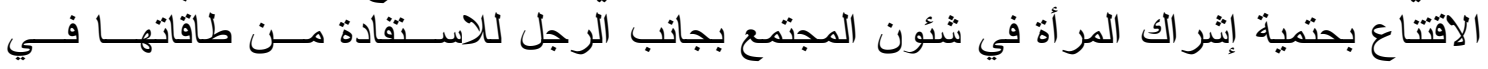
المشرو عات و البر امج التنموية.

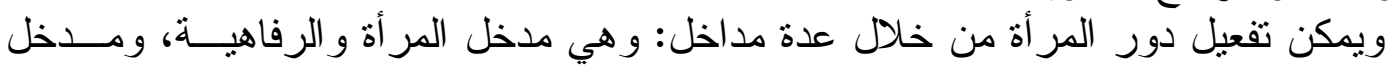

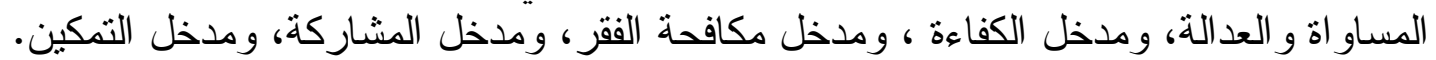
مشكلة البحث: المبث:

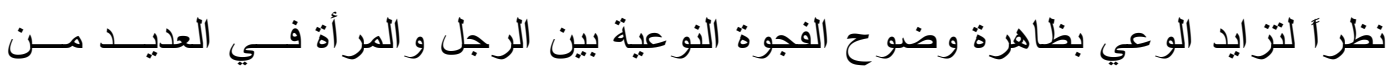

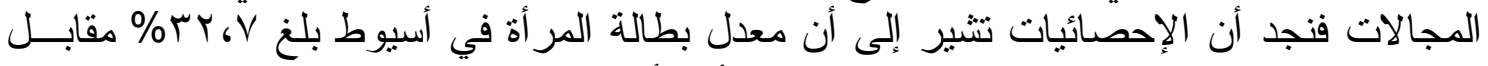

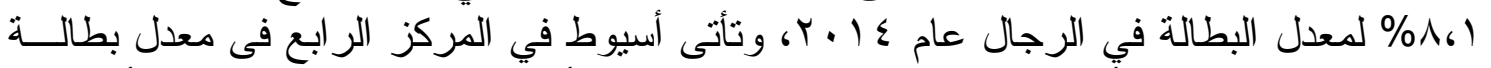

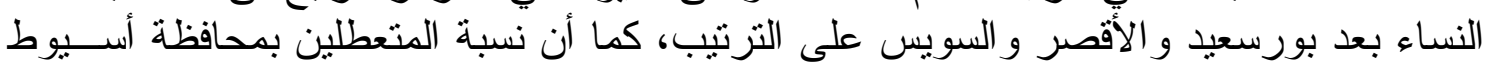
من النساء V.V.

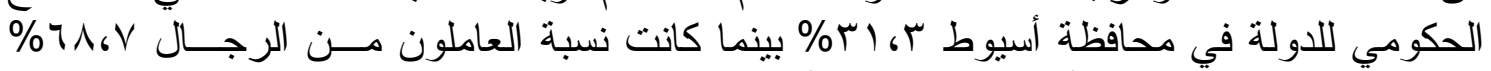

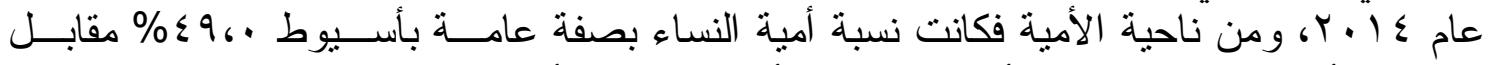

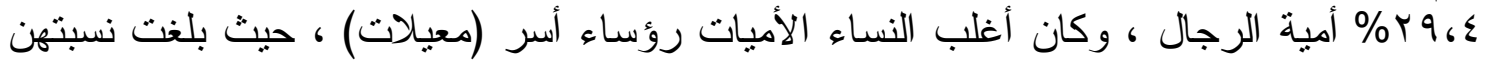

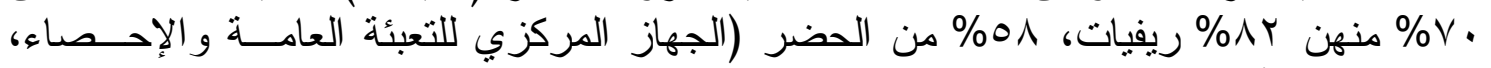

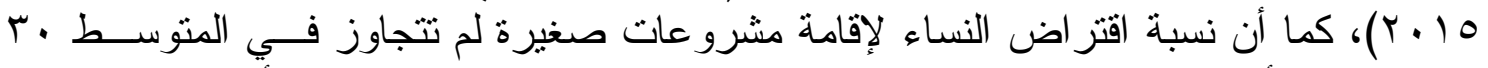

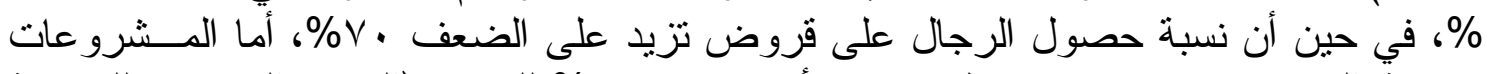

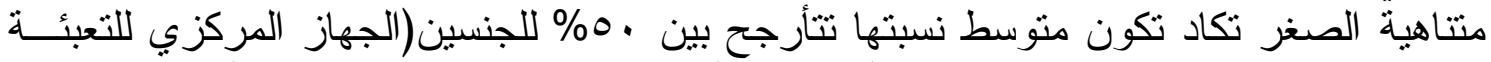

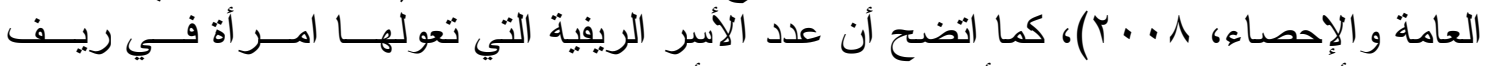

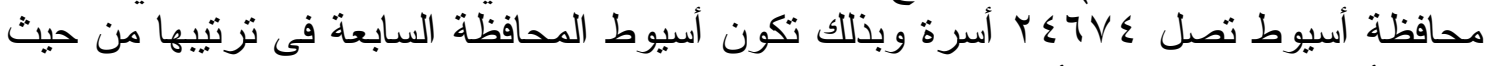

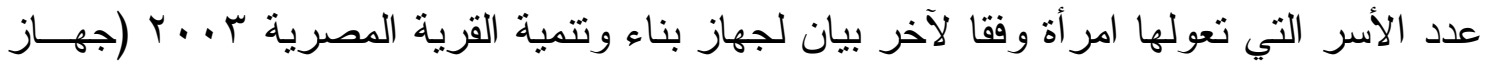

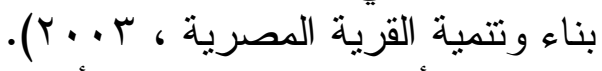
وقد أكدت التقارير الدولية أن حو الي ثلث فقر اء العالم من النساء، وتعتبر النساء المعيلات

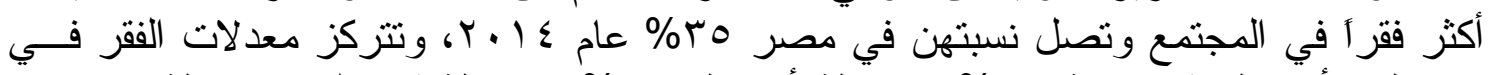

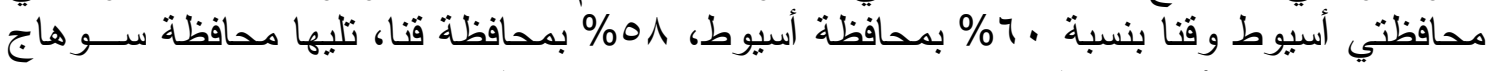

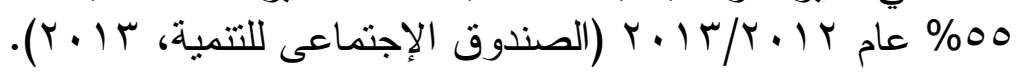

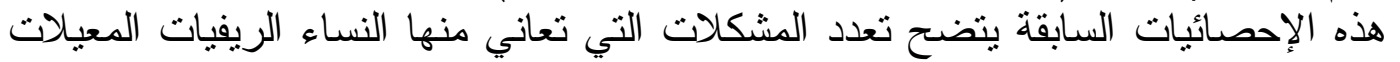

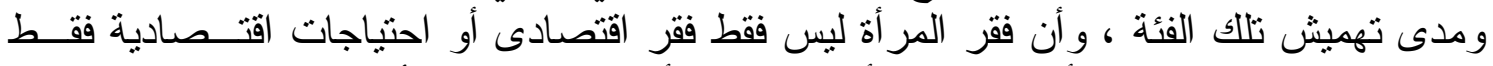

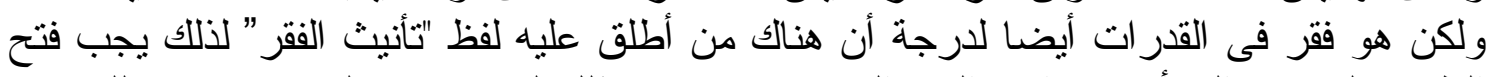

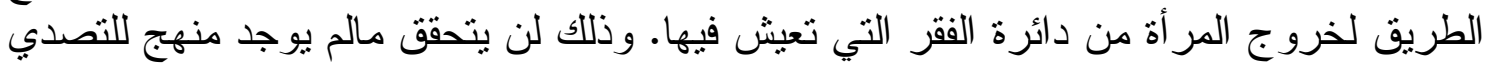


يتمثل الهدف الرئيسى فى دراسة طرق او كيفية التمكين الاقتصادى و الاجتهــاعى للمــر أة المعيلة بريف محافظة اسيوط من خلال تحديد الأهداف الفرعية التئل التالية:

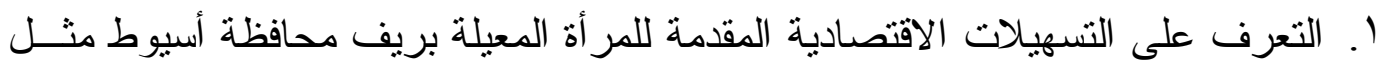

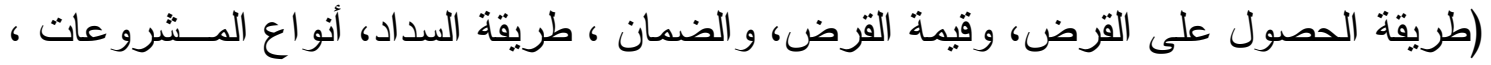

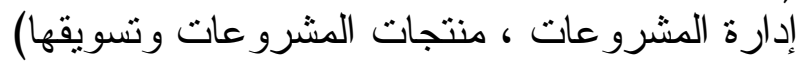

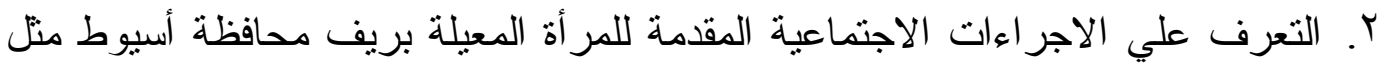

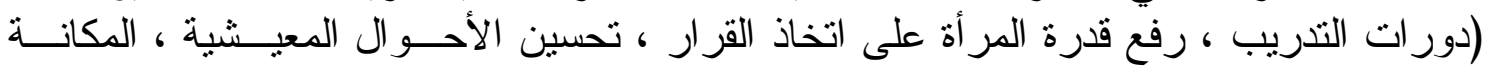

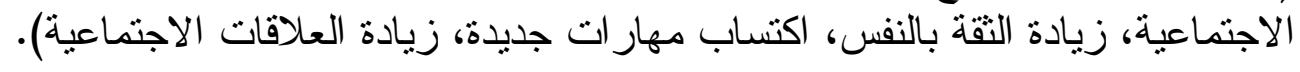

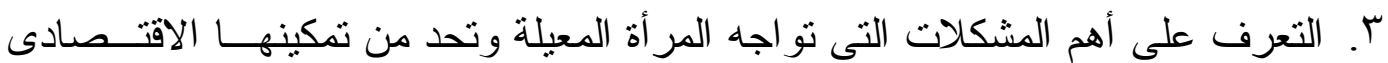

و الاجتماعى بريف المحافظة.

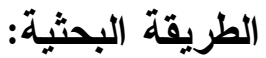
مجتمع وعينة الدر اسة البة يقصد بمجال الدراسة الإطار الذى أجريت فيه الدراسة، حيث ينت ذللك وفق ثلاث مجالات

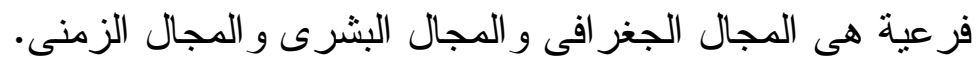

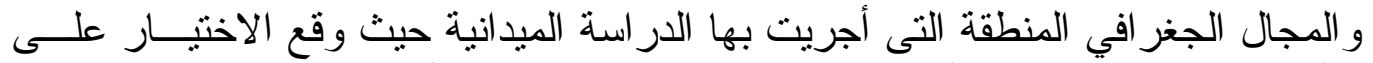

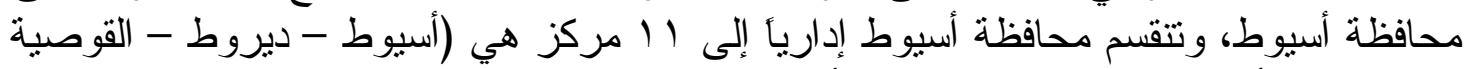

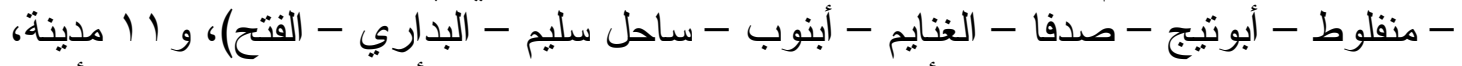

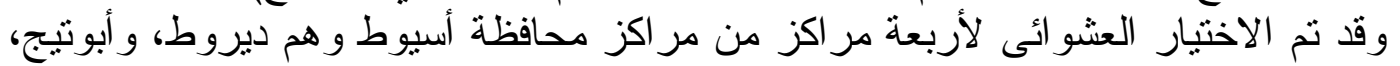

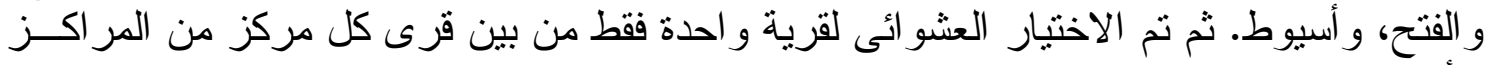

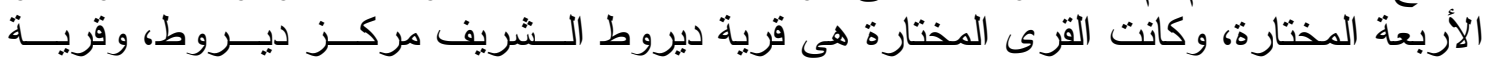

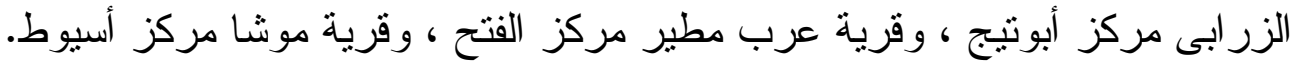

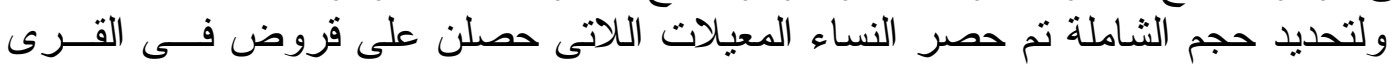

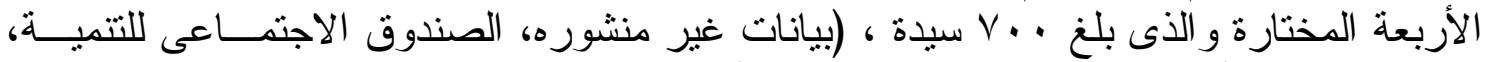

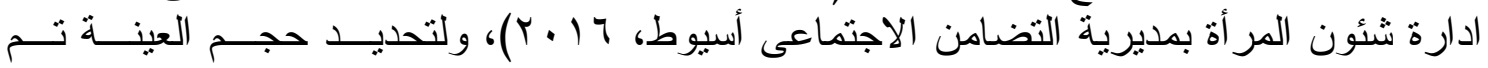

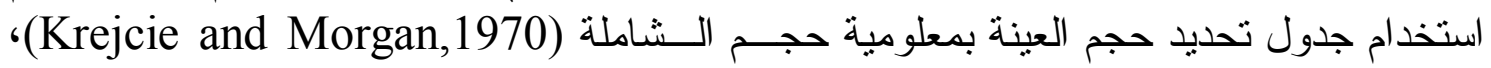

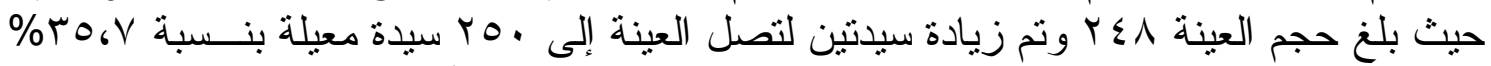

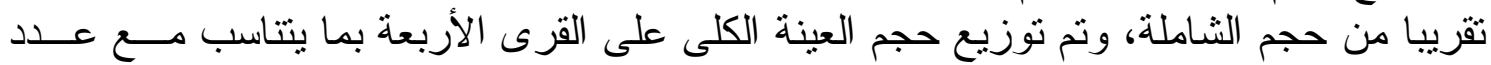

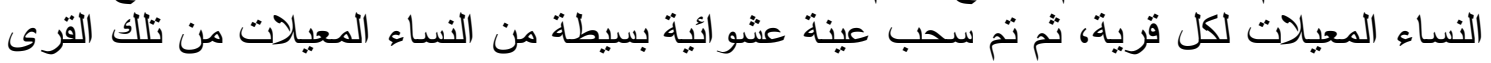

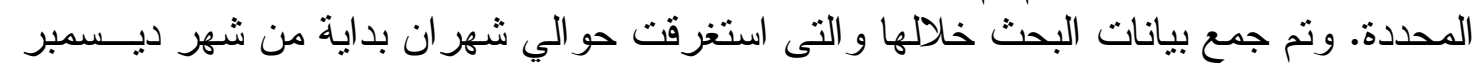

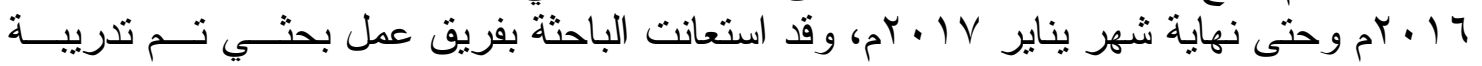

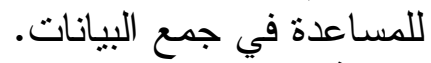

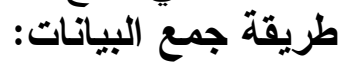

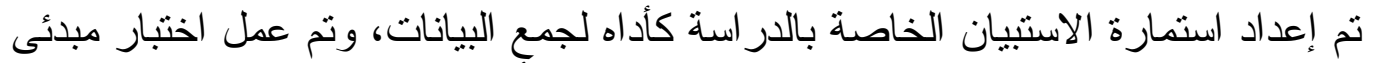

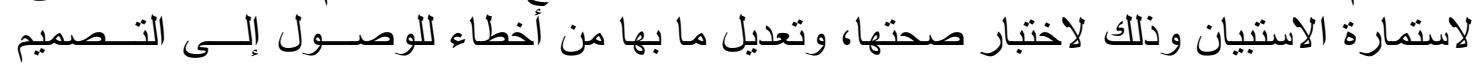

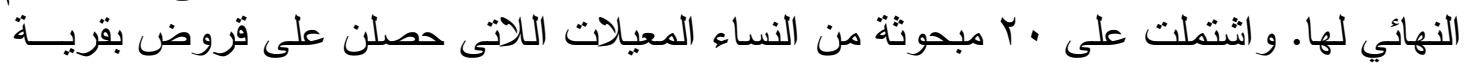

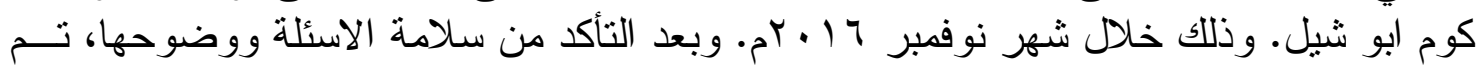

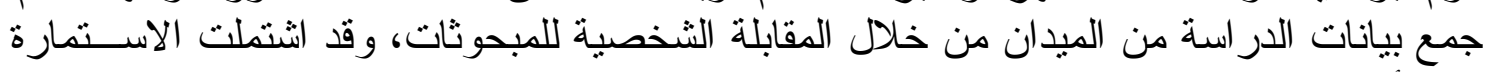

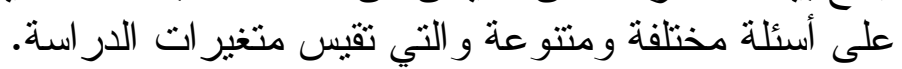
أدوات التحليل الإحصائي العرض الجدولى بالتكر ار و النسب المئوية . 


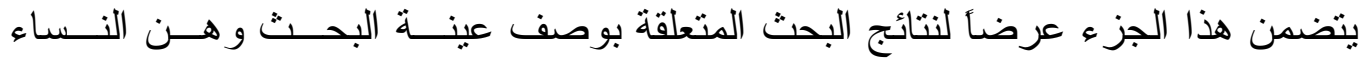

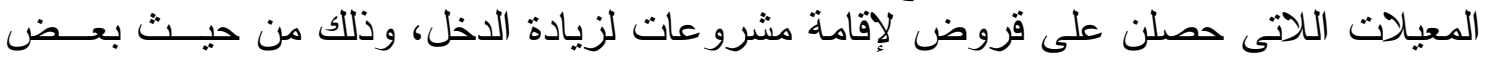

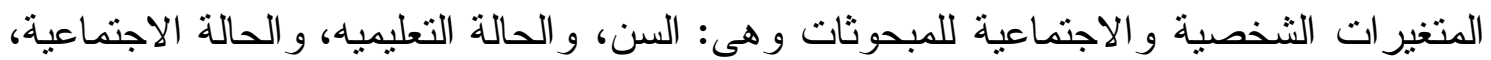

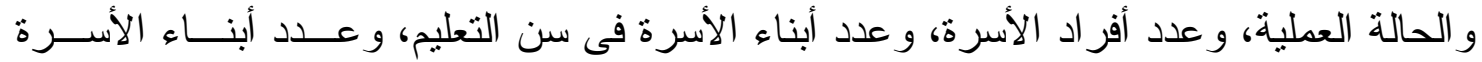

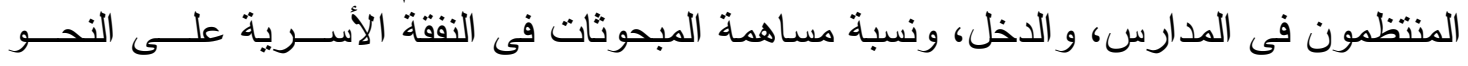
التالى :

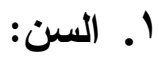

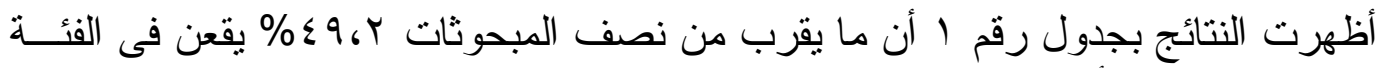

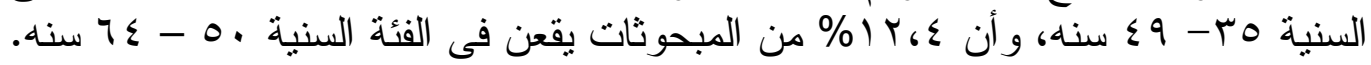

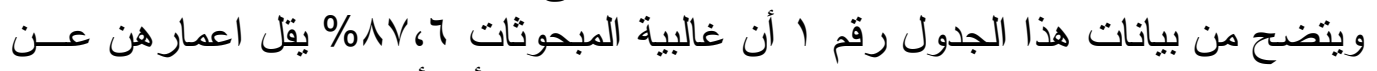

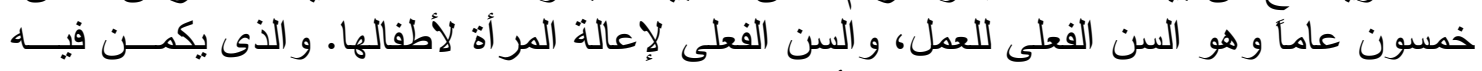

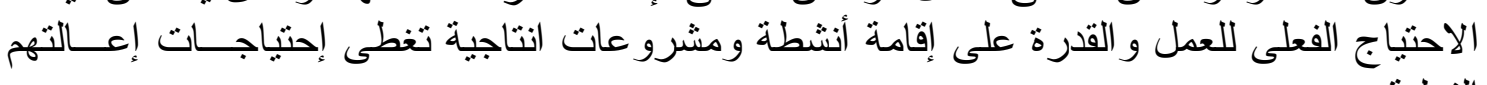

جدول (1) توزيع المبحوثات وفقاً لسنهم

\begin{tabular}{|c|c|c|c|}
\hline$\%$ & عدد & فئات السن & \\
\hline$\Gamma \Lambda_{6} \varepsilon$ & 97 & . r- & - \\
\hline$\sum 9, r$ & Tr & هץ- 9 § سنه & - \\
\hline Mr & ri & .0- 1 سنه & - \\
\hline $1 \cdots 6$ & ro. & المجمو ع & \\
\hline
\end{tabular}

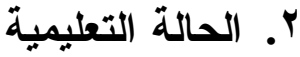

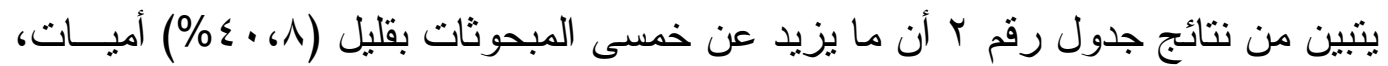

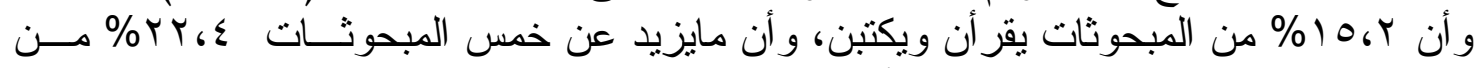

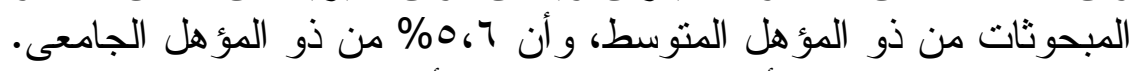

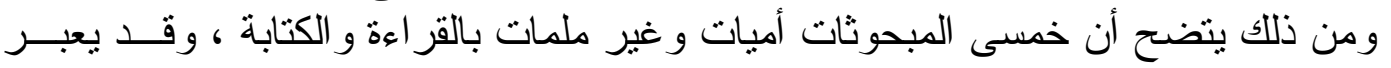

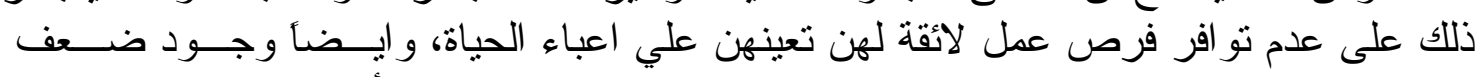

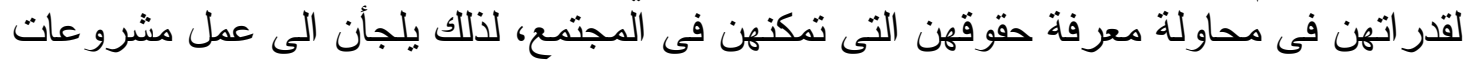

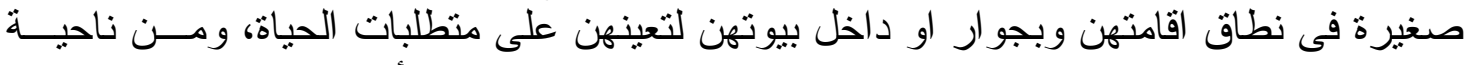

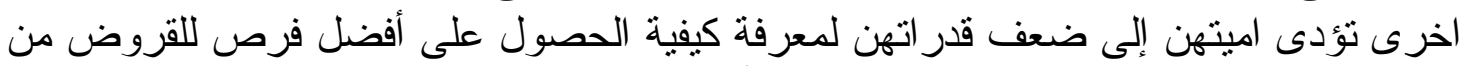

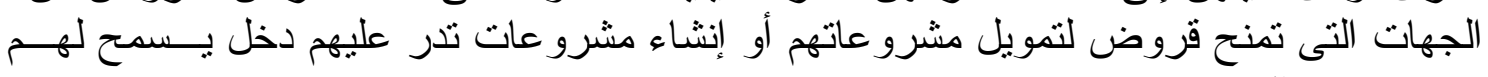
من تمكينهن اقتصاديا فى مجتمعاتهن فئن

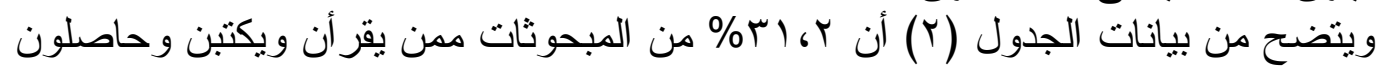

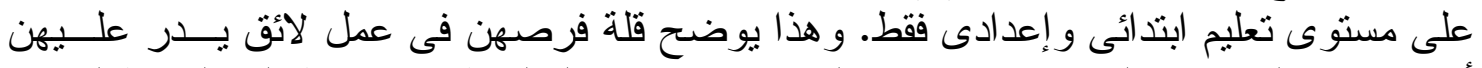

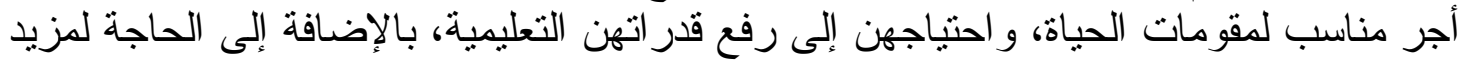

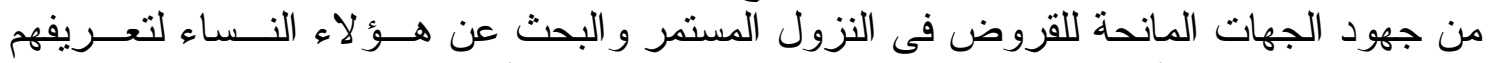

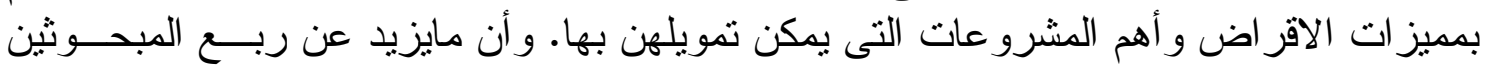

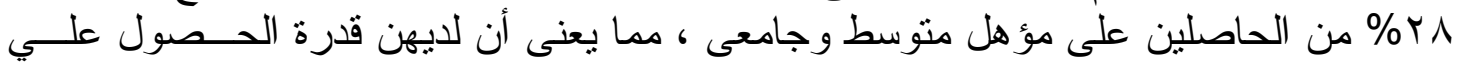




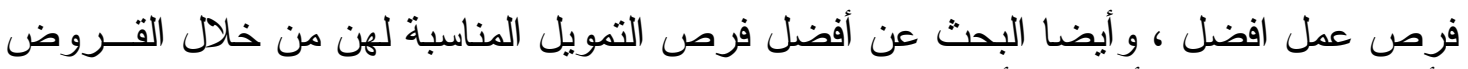
و أيضا التعرف على أفضل الأساليب التى تمكنهن اقتصادياً فى المجتمع. 
جدول رقم (ץ) توزيع المبحوثات وفقاً لمستوى تعليمهن

\begin{tabular}{|c|c|c|}
\hline$\%$ & عدد & المستوى التعليمى \\
\hline$\varepsilon \cdot 6 \wedge$ & $1 \cdot r$ & أمية \\
\hline 10,5 & rᄉ & تقر أ وتكتب \\
\hline 7.5 & 17 & إبتدائى \\
\hline 9.7 & $r \varepsilon$ & إعدادى \\
\hline r r $6 \varepsilon$ & 07 & مؤ هل منوسط \\
\hline 0.7 & $1 \varepsilon$ & مؤ هل جامعى \\
\hline $1 \cdots$ & ro. & المجموع \\
\hline
\end{tabular}

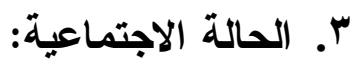

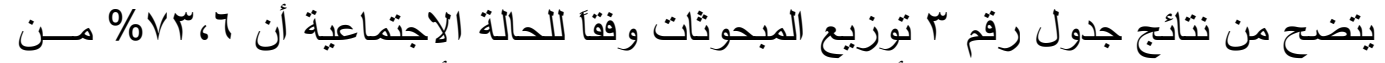

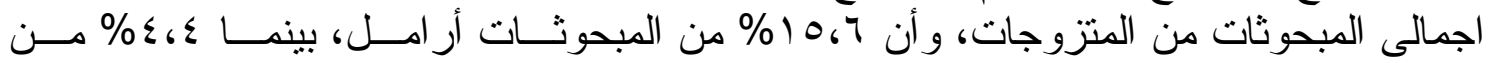
المبحوثات مطلقات، و وعزباء.

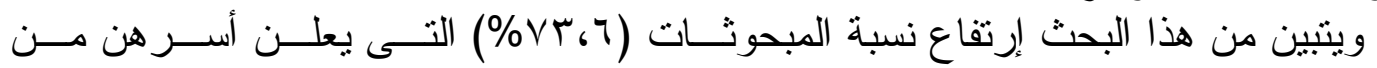

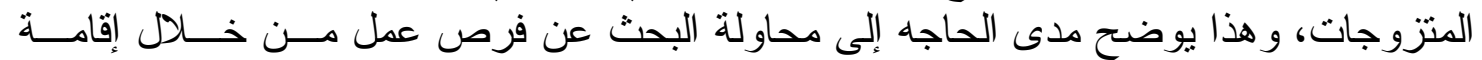

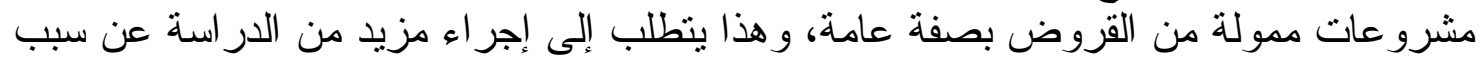

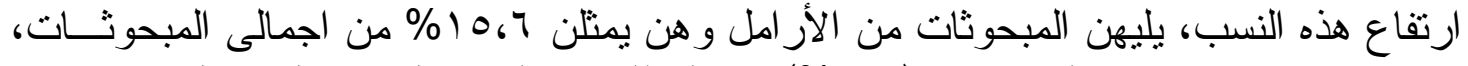

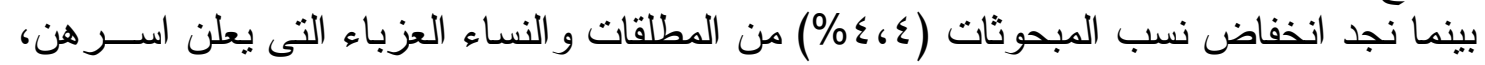

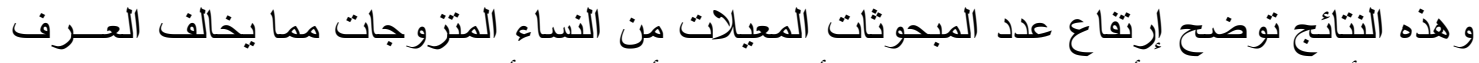

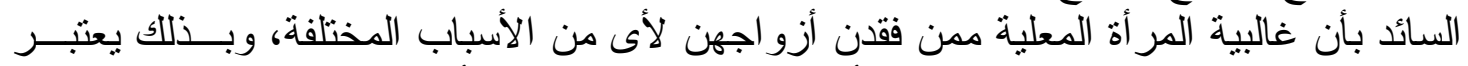

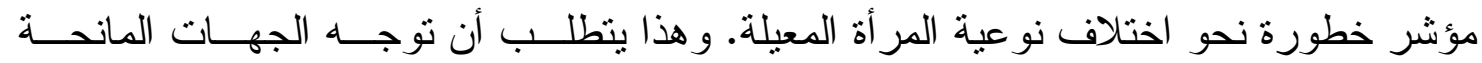

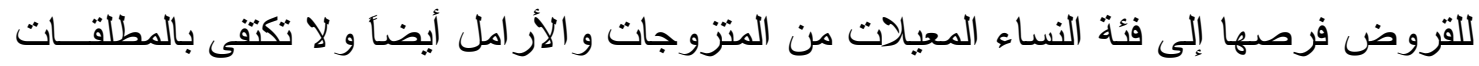
و المهجور ات فقط لكى تمكنهن اقتصاديا فى مجتمعاتهن. جدول رقم (ץ) توزيع المبحوثات وفقاً لحالتهن الاجتماعية

\begin{tabular}{|c|c|c|}
\hline$\%$ & عدد & الحالة الاجتماعية \\
\hline$\varepsilon_{6} \varepsilon$ & 11 & عزباء \\
\hline$V r_{6} T$ & $11 \varepsilon$ & منزوجه \\
\hline 10.7 & $r q$ & أرملة \\
\hline$\varepsilon_{6} \varepsilon$ & 11 & مطلقة \\
\hline$r_{6}$. & 0 & مهجورة \\
\hline $1 \ldots$ & ro. & المجموع \\
\hline
\end{tabular}

المصدر : جمعت وحسبت من العينة البحثية

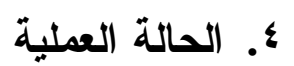

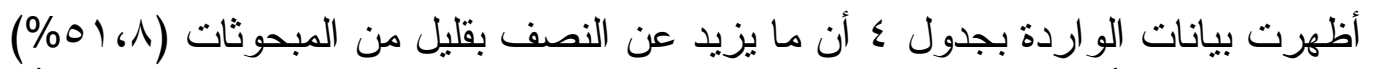

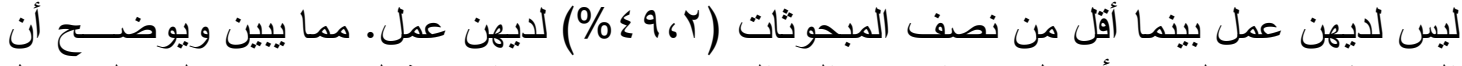

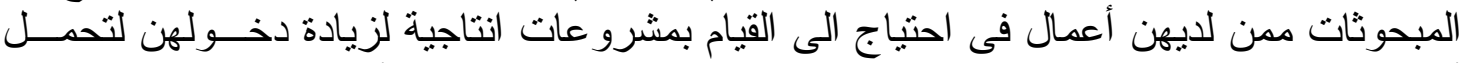

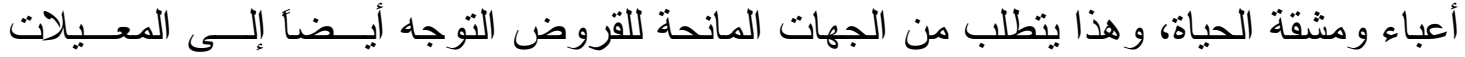
العاملات للقيام بأنشطة إنتاجية لزيادة تمكينهن فى مجتمعاتهم. 
جدول رقم (ع ) توزيع المبحوثات وفقاً لحالتهن العملية

\begin{tabular}{|c|c|c|}
\hline$\%$ & عدد & الحالة العملية \\
\hline$\varepsilon 9, Y$ & ITr & تعمل \\
\hline 0161 & ITV & لا تعمل \\
\hline $1 \cdots \cdot \cdot$ & Yo. & المجموع \\
\hline
\end{tabular}

•. عدد أفراد الأسرة المرأة المعيلة

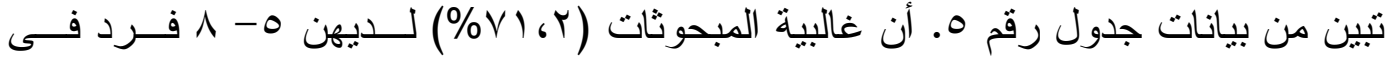

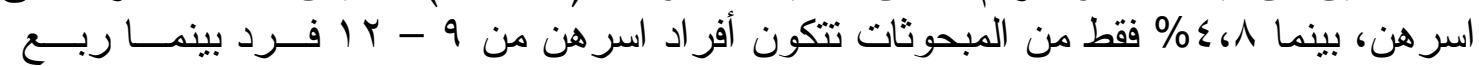

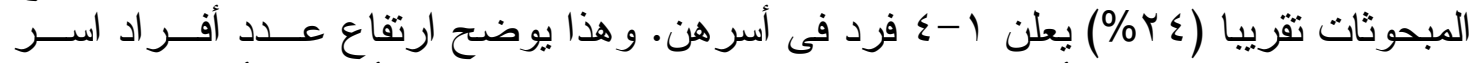

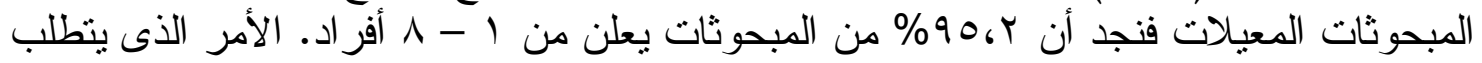

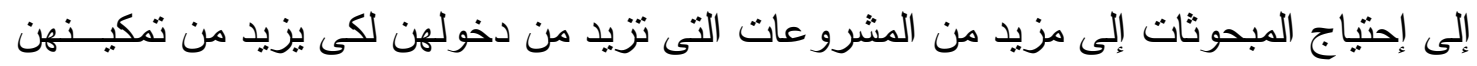

اقتصادياً.

جدول رقم (•) توزيع المبحوثات وفقاً لعدد أفراد الأسرة

\begin{tabular}{|c|c|c|}
\hline$\%$ & عدد & عدد أفر اد الأسرة \\
\hline$r \varepsilon_{6}$. & 7. & 1 \\
\hline$V / 6 r$ & IVA & - - م أفر اد \\
\hline$\varepsilon_{6} \wedge$ & ir & q - r ا فرد \\
\hline $1 \cdots$ & ro. & المجموع \\
\hline
\end{tabular}

المصدر: جمعت وحسبت من العينة البحثية

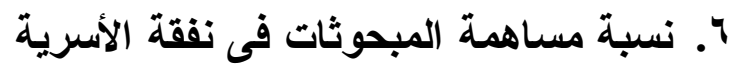

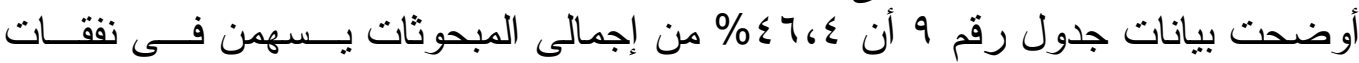

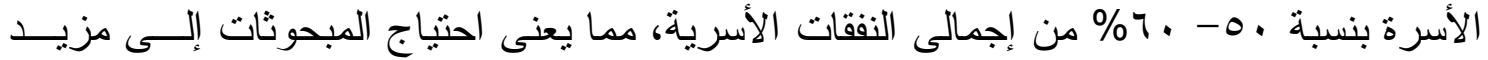

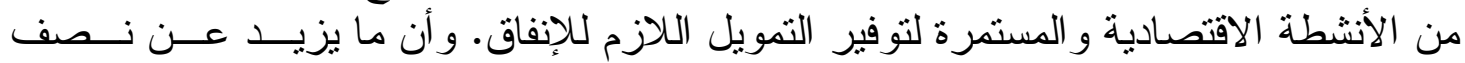

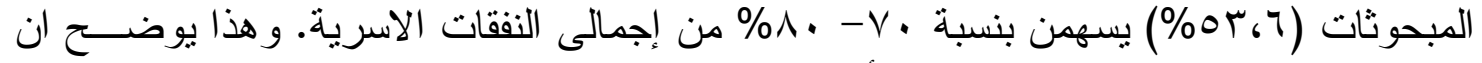

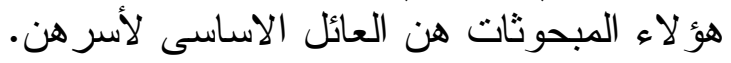

جدول رقم (؟) توزيع المبحوثات وفقاً لنسبة مساهمتهن في نفقة لأهن الأسرة

\begin{tabular}{|c|c|c|}
\hline$\%$ & عدد & نسبة المساهمة \\
\hline YY.. & 70 & $\% 0$. \\
\hline$r \cdot ، \varepsilon$ & 01 & $\% 7$. \\
\hline YY، & 77 & $\% \vee$. \\
\hline TV.r & 71 & $\% \wedge$. \\
\hline $1 \ldots$ & TO. & المجموع \\
\hline
\end{tabular}

V . نوع المشروع التى تعمل به المرأة المعيلة:

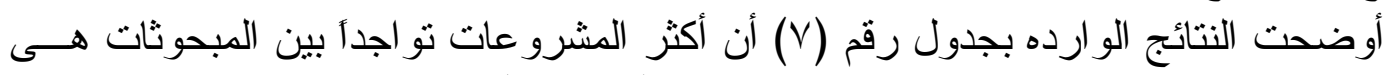

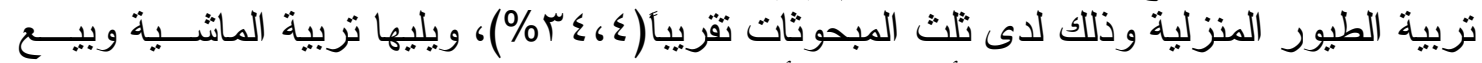

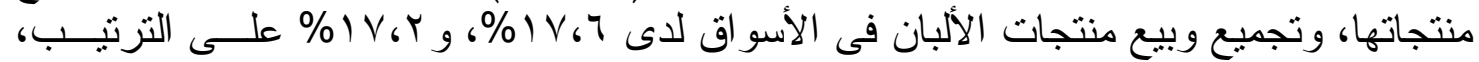


r.lV ، محد و آخرين

http://ajas.js.iknito.com/

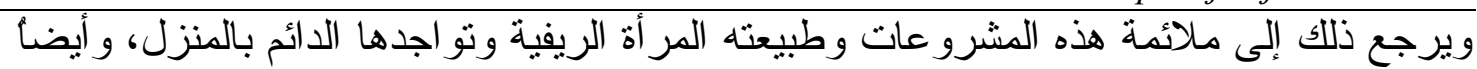

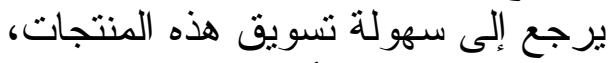

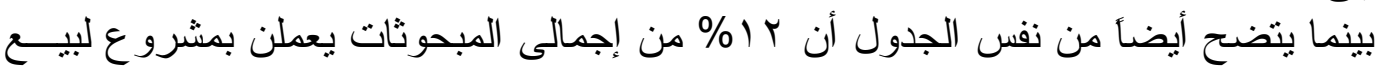

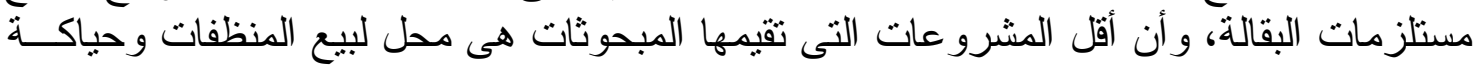

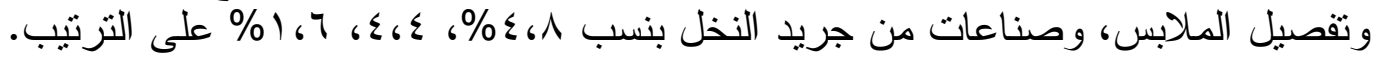

جدول رقم (V) توزيع المبحوثات وفقاً لنوع المشروع التى تعمل به

\begin{tabular}{|c|c|c|}
\hline$\%$ & عدد & نوع المشروع \\
\hline$r \varepsilon$ & $\wedge 7$ & تربية طيور منزلية \\
\hline 1867 & $\varepsilon \varepsilon$ & تربية الماشية \\
\hline IVGr & $\varepsilon r$ & تجميع الألبان بيع منتجاتها بالأسواق \\
\hline $1 r_{6}$ & $r$. & بيع السلع التموينية (البقالة) \\
\hline$\Lambda_{6} \cdot$ & $r \cdot$ & بيع ملابس جاهزة \\
\hline$\varepsilon_{6} \wedge$ & ir & محل لبيع المنظفات \\
\hline$\varepsilon$ « & 11 & حياكة وتفصيل الملابس \\
\hline 167 & $\varepsilon$ & صناعات من جريد النخل \\
\hline $1 \cdots$ & ro. & المجموع \\
\hline
\end{tabular}

المصدر: جمعت وحسبت من العينة البحثية

^. أسباب اختيار المشروع الأى تعمل به المرأة المعيلة:

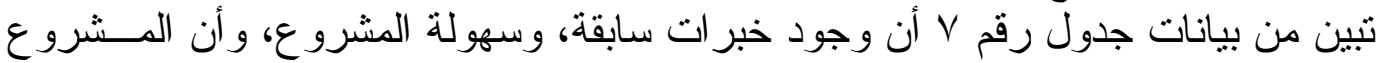

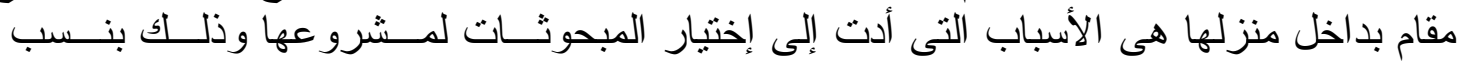

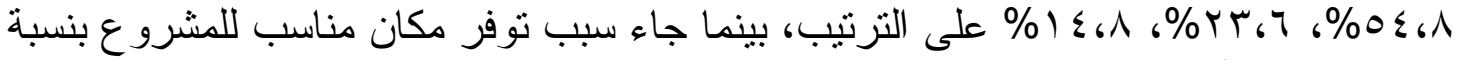

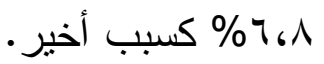

نستتج من ذلك أن الخبر ات السابقة كان السبب الرئيسى فى اختيار المبحوثات لمشروعها

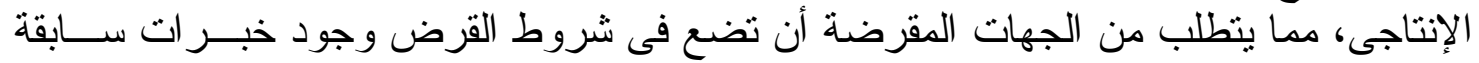

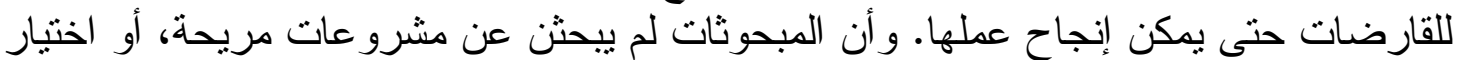

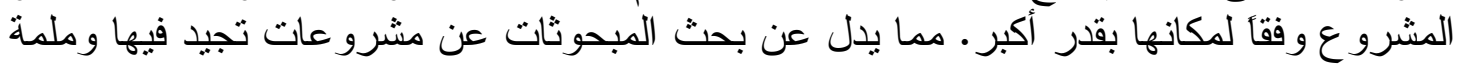

جدول رقم (^) توزيع المبحوثات وفقاً لأسباب اختيار المشروع الذى تعمل به

\begin{tabular}{|c|c|c|}
\hline$\%$ & عدد & الأسباب \\
\hline $0 \leqslant 6 \wedge$ & ITV & وجود خبرة سابقة في هذا المشروع \\
\hline$r T_{6}$ & 09 & سهولة المشروع واريحيته \\
\hline $1 \leqslant 61$ & rv & لعملها في المشروع من داخل المنزل \\
\hline 7,1 & IV & توفر مكآن مناسب لعمل المشروع \\
\hline $1 \cdots \cdot \cdot$ & ro. & المجموع \\
\hline
\end{tabular}

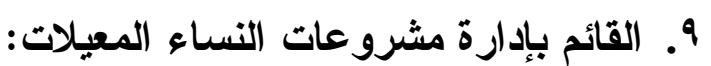

تبين من بيانات جدول رقم 9.

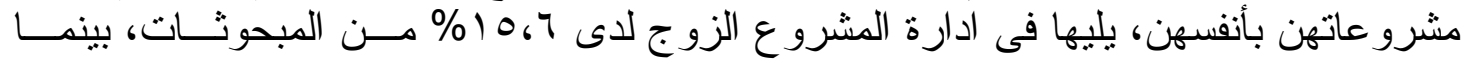


^، †\% من المبحوثات وجد أن الثريك يدير الششروع، و أقل المبحوثات تنتعين بأبناها فى إدارة

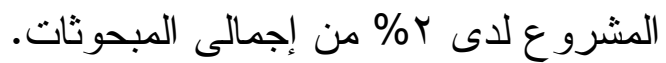

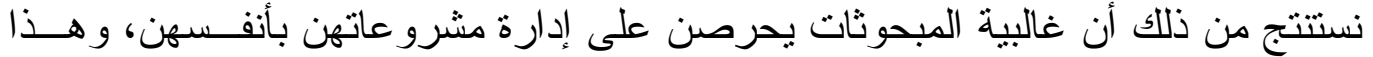

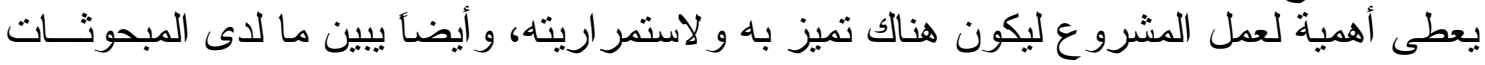

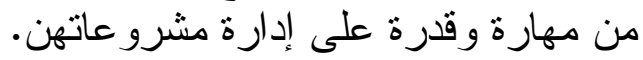
جدول رقم (9) توزيع أستجابات المبحوثات وفقاً لمن يدير مشروعاتهر

\begin{tabular}{|c|c|c|}
\hline$\%$ & عدد & الأستجابة \\
\hline vort & 1199 & تدير المشروع بنفسها \\
\hline 7,1 & iv & 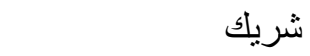 \\
\hline 10,7 & rq & 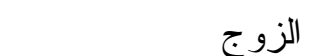 \\
\hline$r_{6} \cdot$ & 0 & أحد الأبناء \\
\hline $1 \ldots 6$ & ro. & المجموع \\
\hline
\end{tabular}
•

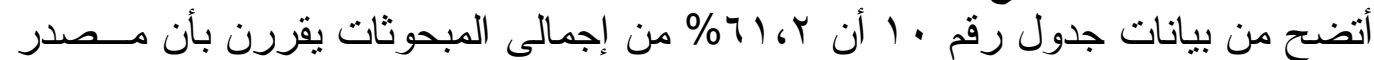

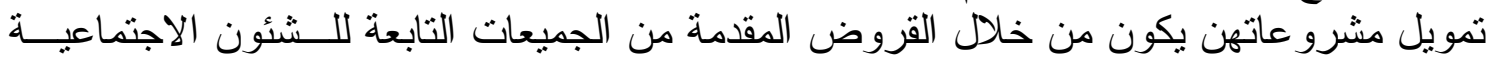

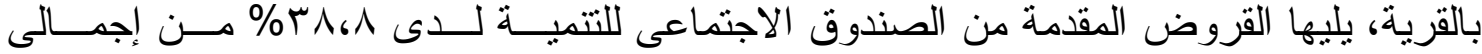

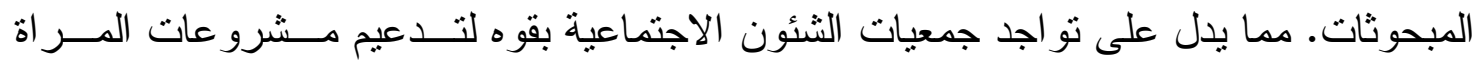

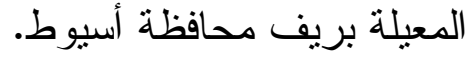
جدول رقم (• 1) توزيع أستجابات المبحوثات وفقاً لمصدر تمويل المشروع

\begin{tabular}{|c|c|c|}
\hline$\%$ & علد & مصدر التمويل \\
\hline 71,4 & 104 & 1- قروض مقدمة من الجمعية التابعة للشئون \\
\hline$r \Lambda_{6} \Lambda$ & qv & 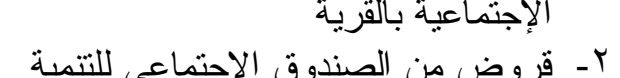 \\
\hline $1 \ldots$ & To. & المجمو ع \\
\hline
\end{tabular}

المصدر: جمعت وحسبت من العينة البحثية

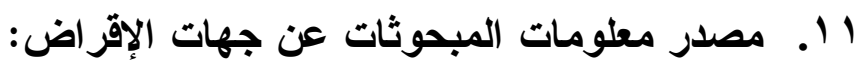

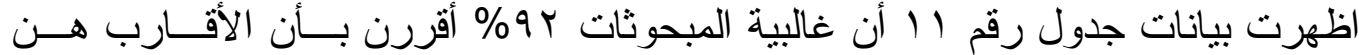

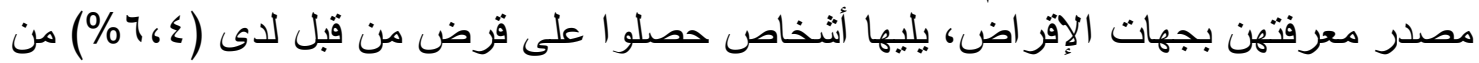

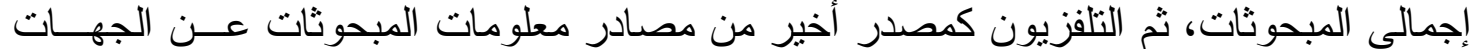

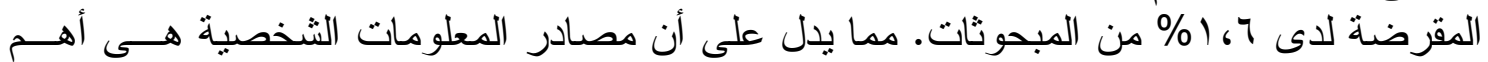

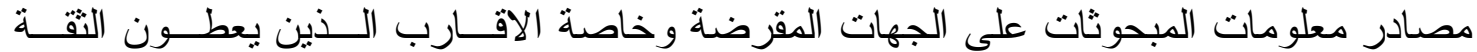

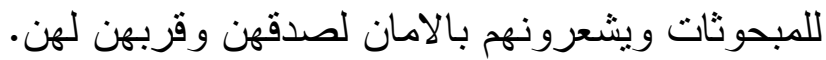


r.lV ، محد و وآخرين

http://ajas.js.iknito.com/

جدول رقم (11) توزيع أستجابات المبحوثات وفقاً لمصدر معلوماتهم عن الجهات المقرضة:

\begin{tabular}{|c|c|c|}
\hline$\%$ & عدد & مصدر السماع \\
\hline $9 r_{6}$. & rr. & • الاقارب \\
\hline $7 ، \varepsilon$ & 17 & •أفر اد حصلو ا على قروض \\
\hline 1.7 & $\varepsilon$ & • • التليفزيون \\
\hline $1 \cdots$ & Yo. & مجموع \\
\hline
\end{tabular}

r 1 ا. مدة الزمنية التى تستغرقها فى الحصول على القرض.

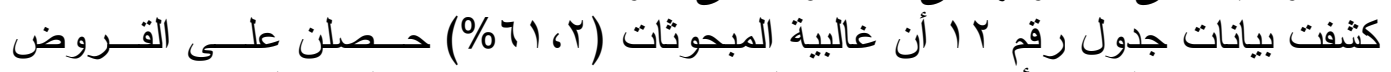

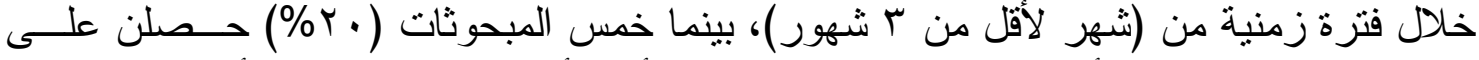

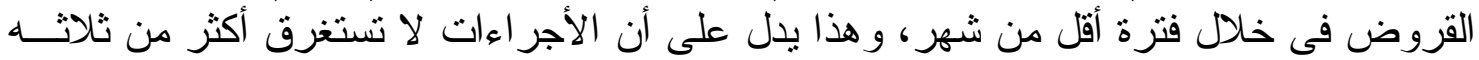

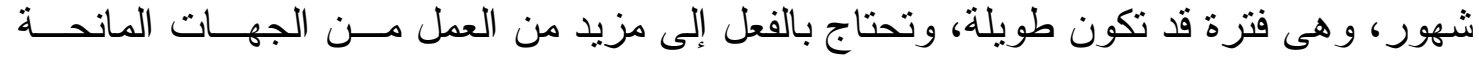

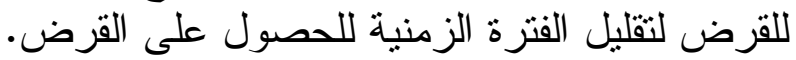
جدول رقم (r I ) توزيع أستجابات المبحوثات وفقاً للمدة الزمنية للحصول على القرض

\begin{tabular}{|c|c|c|}
\hline$\%$ & عدد & المدة الزمنية \\
\hline r... & 0 . & أقل من شهر \\
\hline 7164 & 104 & من شهر لاقل من ب شهور \\
\hline $1 \Lambda_{6} \wedge$ & $\varepsilon V$ & من ثنلاث شهور فأكثر \\
\hline $1 \cdots$ & YO. & المجموع \\
\hline
\end{tabular}

با 1. سهولة إجراءات الحصول على القرض:

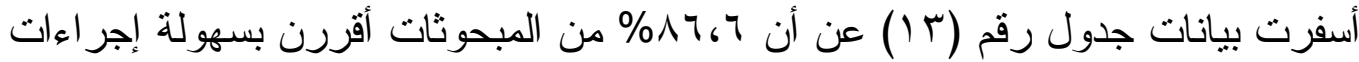

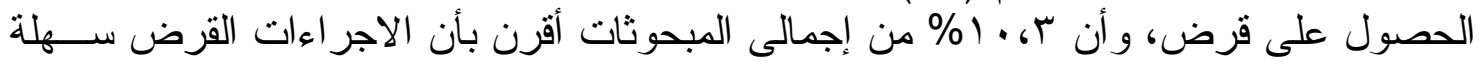

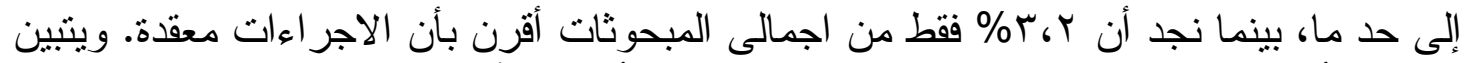

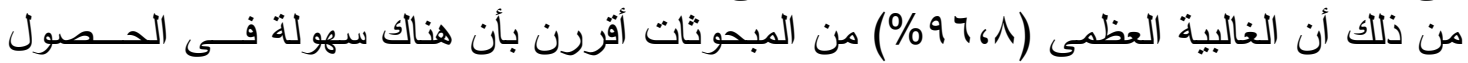

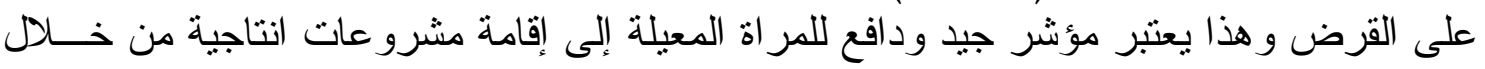

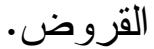
جدول رقم (T ا I) توزيع أستجابات المبحوثات وفقاً لسهولة الاجراءات القرض

\begin{tabular}{|c|c|c|}
\hline$\%$ & عدد & سهولة جراعات \\
\hline$\wedge 7_{6}$. & Y10 & سهل \\
\hline $1 \cdot 61$ & $r V$ & سهل الى حد ما \\
\hline ror & $\wedge$ & معقد \\
\hline $1 \ldots$ & ro. & المجموع \\
\hline
\end{tabular}

ع 1. مناسبة فترات سداد قيمة القرض:

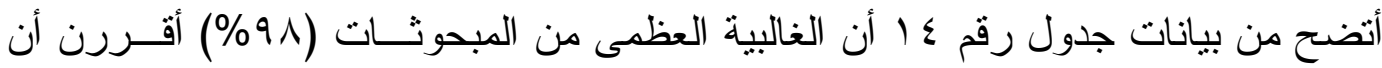

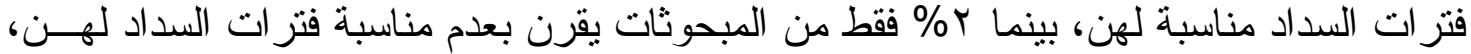

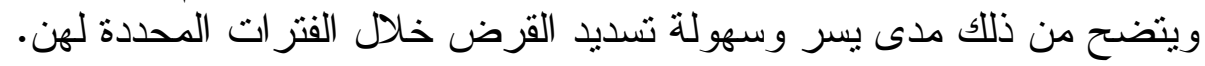


جدول رقم (ع ا ) توزيع أستجابات المبحوثات وفقاً للمناسبة فترات سداد القرضة

\begin{tabular}{|c|c|c|}
\hline$\%$ & عدد & المناسبة \\
\hline $9 \lambda_{6}$. & $r \leqslant 0$ & مناسبة \\
\hline Y.. & 0 & غير مناسبة \\
\hline $1 \ldots$ & ro. & المجموع \\
\hline
\end{tabular}

ه ا. الاتظظام فى سداد قيمة القرض:

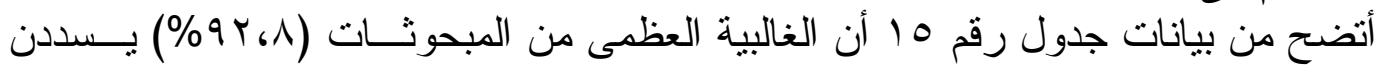

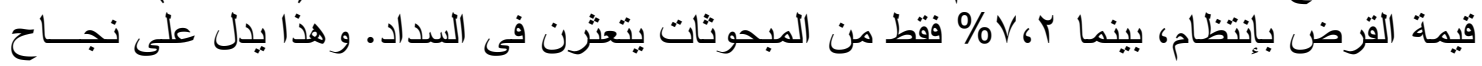

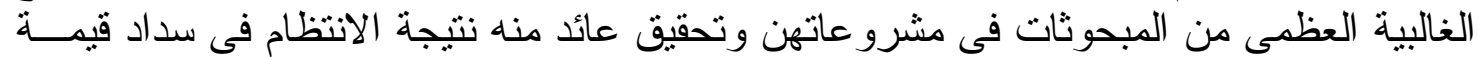
القرض فى المو اعيد المحددة له. جدول رقم (10) توزيع أستجابات المبحوثات وفقاً لاتنظامهن فى سداد قيمة القرض

\begin{tabular}{|c|c|c|}
\hline$\%$ & عداد ( ع ال & طبيعة السداد \\
\hline $9 Y_{6} \wedge$ & THY & منتظمة \\
\hline$V_{6} r$ & 11 & متعثرة \\
\hline $1 \ldots$ & ro. & المجموع \\
\hline
\end{tabular}

المصدر: جمعت وحسبت من العينة البحثية 19. أسباب التعثر فى سداد قيمة القرض:

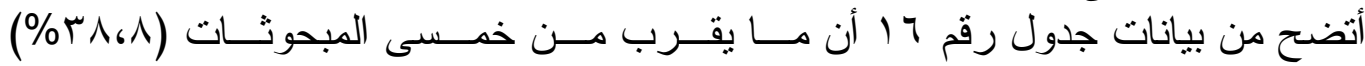

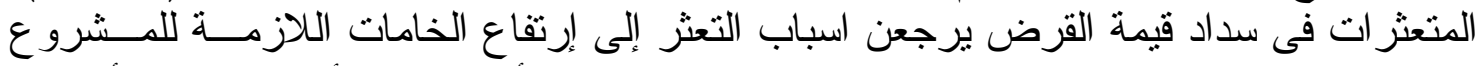

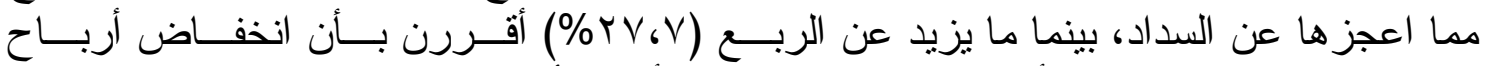

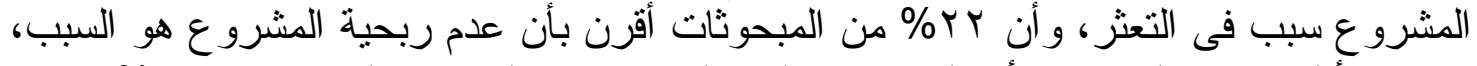

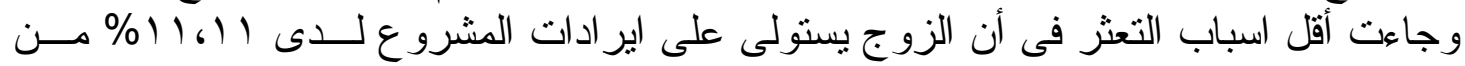

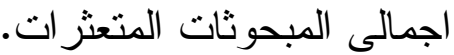

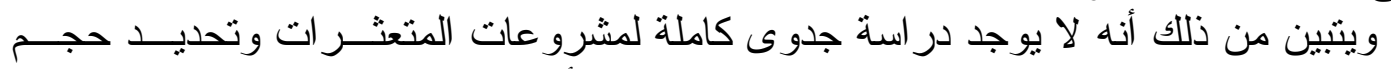

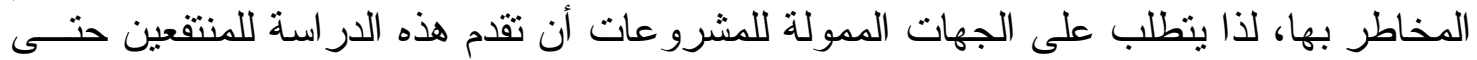
يتسنى لها سداد الاقساط وقيمة القرض في مو عدة.

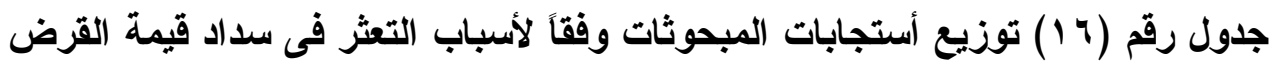

\begin{tabular}{|c|c|c|}
\hline$\%$ & عدد & سبب التثر \\
\hline$\left\langle V_{6} V \lambda\right.$ & 0 & انخفاض ربحية المشروع \\
\hline$r \Lambda_{6} \wedge 9$ & v & ارتفاع الخامات اللازمة للمشروع \\
\hline 11611 & r & استيلاء الزوج على ايرادات المشروع \\
\hline rr,rY & $\varepsilon$ & المشروع غير مربح على الاطلاق \\
\hline $1 \cdots \cdot \cdot$ & ro. & المجموع \\
\hline
\end{tabular}

المصدر: جمعت وحسبت من العينة البحثية IV

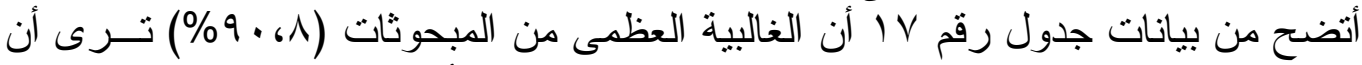

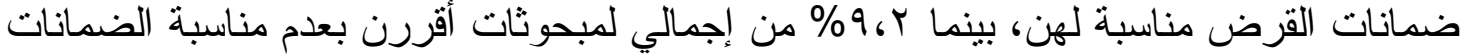

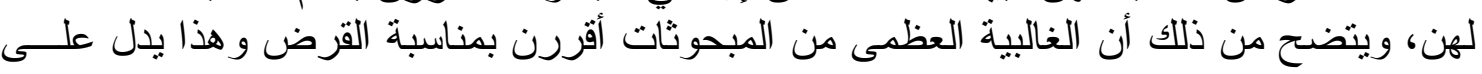




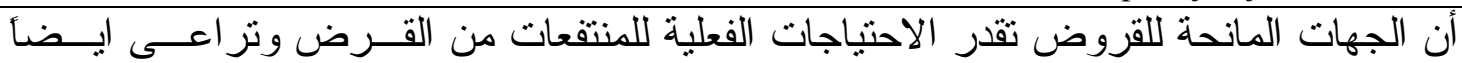

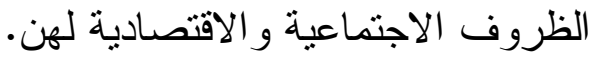

جدول رقم (V V I توزيع أستجابات المبحوثات وفقاً لضمانات الحصول على القرض

\begin{tabular}{|c|c|c|}
\hline$\%$ & عدد & ضمانات القرض \\
\hline $9 \cdot 61$ & YTV & مناسبة \\
\hline 9.4 & r & كثيرة ومعقدة \\
\hline $1 \ldots$ & ro. & المجموع \\
\hline
\end{tabular}

المصدر: جمعت وحسبت من العينة البحثية

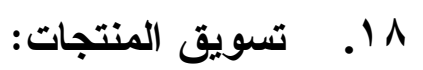

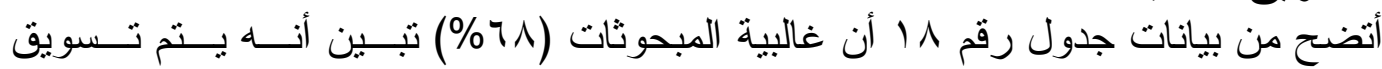

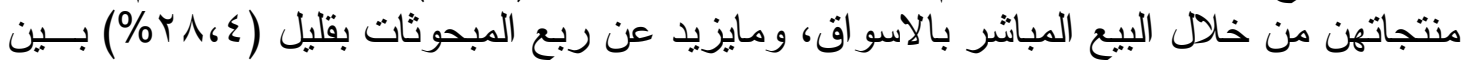

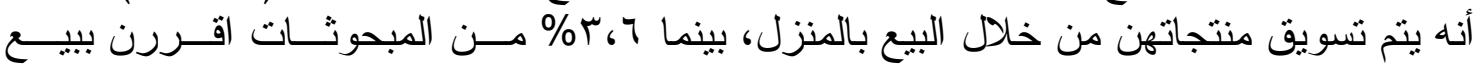

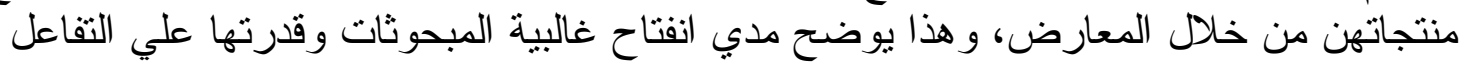
الاجتماعي مع المجتمع المحيط بها.

جدول رقم (1) توزيع أستجابات المبحوثات وفقاً لطرق تسويق المنتجات من وجهة نظرهم

\begin{tabular}{|c|c|c|}
\hline$\%$ & عدد & طرق التسويق \\
\hline $7 \lambda_{6} \cdot$ & iv. & ــ من خلال البيع في الأسواق \\
\hline$r \Lambda_{6} \varepsilon$ & (1) & ـ من خلال البيع في المنزل \\
\hline r.7 & 9 & ـ من خلال البيع في المعارض \\
\hline $1 \cdots \cdot$ & ro. & 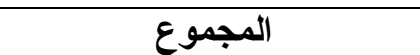 \\
\hline
\end{tabular}

19. دور الجهات القارضة فى تسويق المنتجات

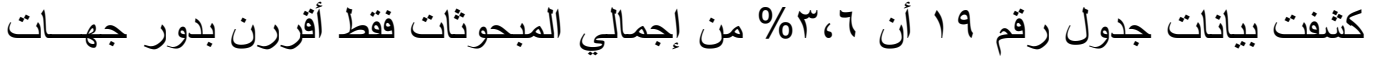

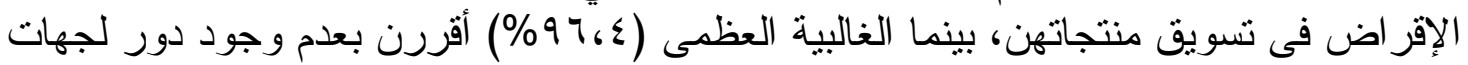

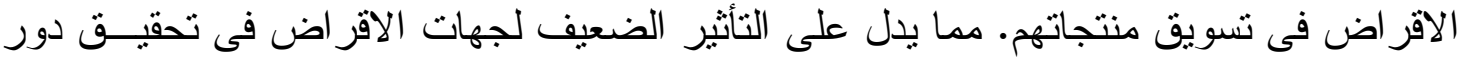
ايجابى وفعال نحو المنتفعات بالقرض نحو تسويق منتجاتهن.

جدول رقم (9 1) توزيع أستجابات المبحوثات وفقاً لدور الجهات القارضة فى تسويق المنتجات

\begin{tabular}{|c|c|c|}
\hline$\%$ & عدد & وجود دور \\
\hline$r_{6.7}$ & 9 & ع \\
\hline $97 ، \varepsilon$ & $r \leqslant 1$ & 3 \\
\hline $1 \ldots$, & ro. & المجموع \\
\hline
\end{tabular}

المصدر : جمعت وحسبت من العينة البحثية

ثثانياً: الأجر اءات الاجتماعية لتمكين المرأة المعيلة من خلا إقامة مشروعات اقتصادية لها فى ريف أسيوط:

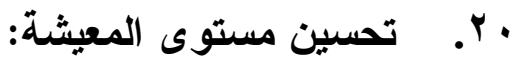




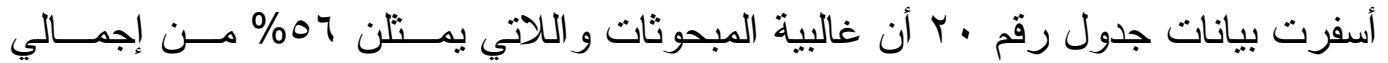

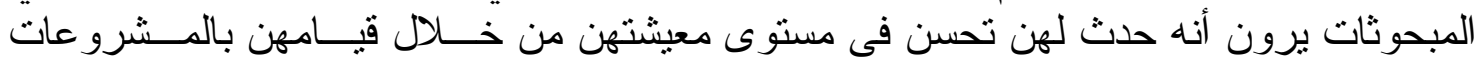

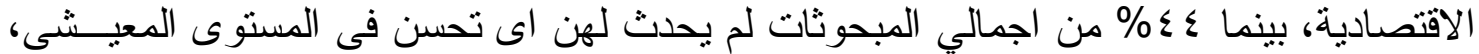
وهذا يوضح أن تتفيذ تلك المشروعات كان لها دور في تحسين المستوى المعيشي.

جدول رقم (·r) توزيع أستجابات المبحوثات وفقاً لمو (فقتهن على تحسن مستوى معيشتهن

\begin{tabular}{|c|c|c|}
\hline$\%$ & عدد & المو افقة \\
\hline 076. & $1 \leqslant$. & نعم \\
\hline$\varepsilon \varepsilon_{6}$. & 11. & y \\
\hline $1 \ldots$ & YQ. & المجموع \\
\hline
\end{tabular}

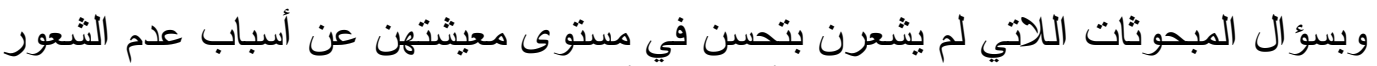

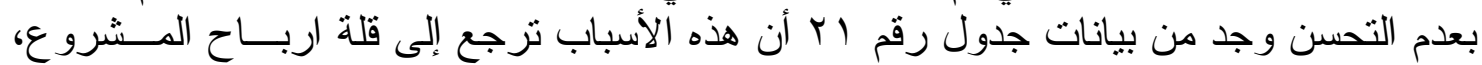

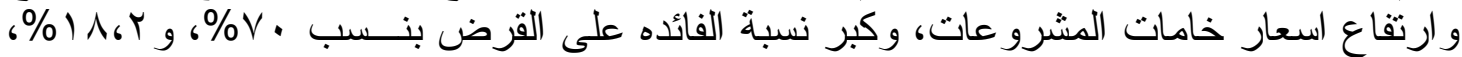

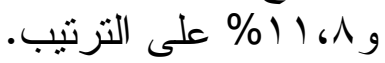

جدول رقم (Y) توزيع أستجابات المبحوثات وفقاً لاسباب عـدم شـعورهن بتحسن فـي مسستوى معيشتهن

\begin{tabular}{|c|c|c|}
\hline$\%$ & عدد & الاسباب \\
\hline$v_{*} \cdot$. & VV & قلة أرباح المشرو ع \\
\hline 1161 & ז & ارتفاع نسبة فائدة القرض \\
\hline $1 A_{6} r$ & r. & ارتفاع أَسعار خامات المشروع \\
\hline $1 \ldots$ & 11. & 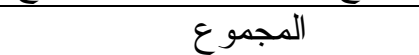 \\
\hline
\end{tabular}

ا Y. . القدرة على ابداء الرأى (أصبح عندك جرأة وبتقولى رأيك دايما):

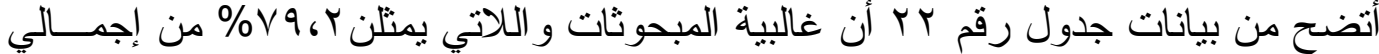

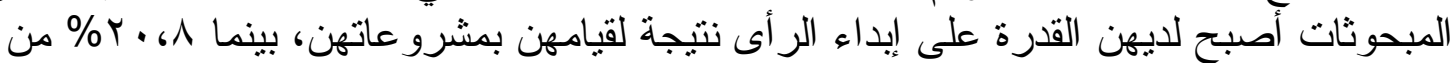

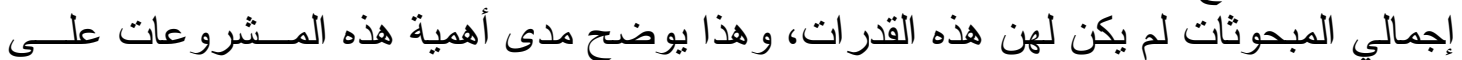
زيادة ثقة المبحوثات بأنفسهن وقدرتهن لعلى التعبير عن أنفسهن.

جدول رقم (Y ) توزيع أستجابات المبحوثات وفقاً لموافقتهن تأثير المشروعات على تقدير الذات

\begin{tabular}{|c|c|c|}
\hline$\%$ & عدد & المو افقة \\
\hline$V q, Y$ & 191 & ع عم \\
\hline$r \cdot ، \wedge$ & or & 2 \\
\hline $1 \ldots$. & ro. & المجموع \\
\hline
\end{tabular}

r r. زيادة العلاقات الاجتماعية (زود علاقتك بالناس): 
r.lV ، محد وآخربين http://ajas.js.iknito.com/

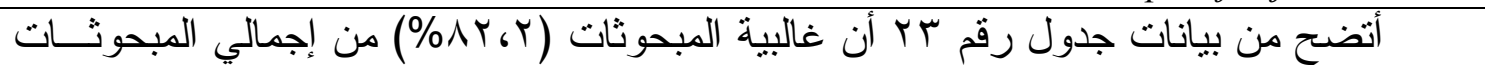

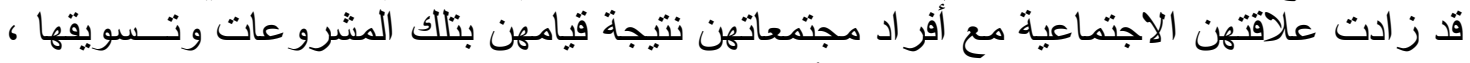

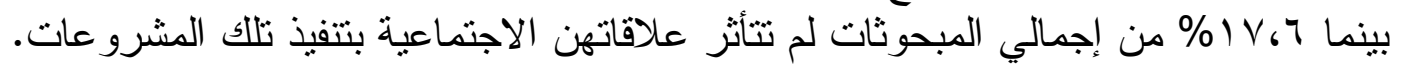


جدول رقم (بr) توزيع أستجابات المبحوثات وفقاً لتحسن علاقاتهن الاجتماعية

\begin{tabular}{|c|c|c|}
\hline$\%$ & عدد & المو اققة \\
\hline$\lambda_{\text {Ar }} \varepsilon$ & $r . T$ & نعم \\
\hline $1 V_{6} 7$ & $\varepsilon \varepsilon$ & $y$ \\
\hline $1 \ldots$ & ro. & المجمو ع \\
\hline
\end{tabular}

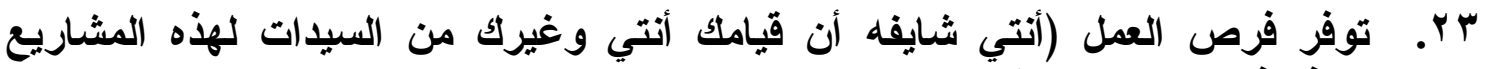
بتوفر فرص عمل ليكم)

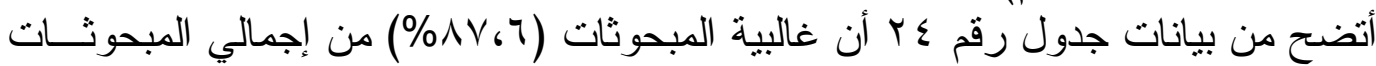

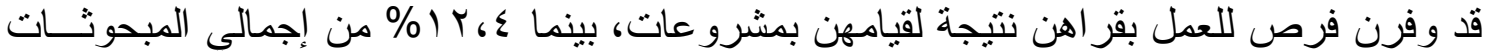

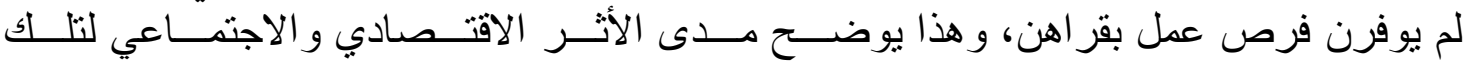

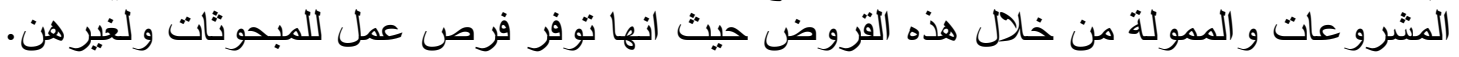

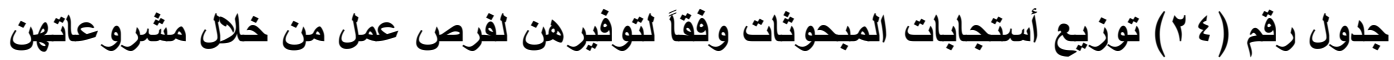

\begin{tabular}{|c|c|c|}
\hline$\%$ & عدد & المو (فقة \\
\hline$\lambda V_{6} t$ & r19 & نعم \\
\hline$I_{6} \varepsilon$ & M & $y$ \\
\hline $1 \ldots$ & Yo. & المجموع \\
\hline
\end{tabular}

צ Y. إكتساب مهارات جديدة (هل اكتسبتي مهارات جديدة في التعامل مع مجتمع القرية بعـد تنفيذك للمشروع)

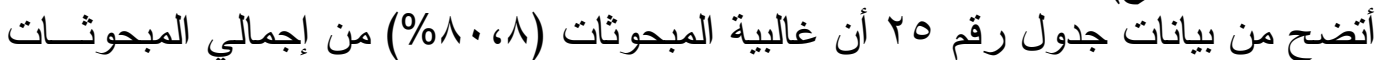

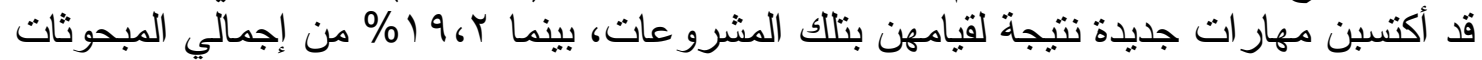

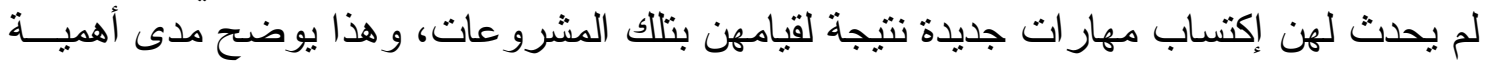

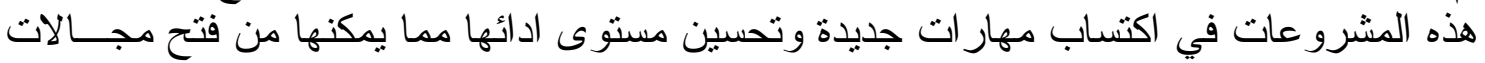

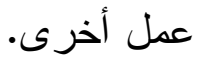

جدول رقم (Y) توزيع أستجابات المبحوثات وفقاً لأكتساب مهارات جديدة:

\begin{tabular}{|c|c|c|}
\hline$\%$ & عدد & المو افقة \\
\hline ג.، & T.r & نعم \\
\hline 19.5 & $\varepsilon \wedge$ & $y$ \\
\hline $1 \ldots$ & ro. & لمجموع ع \\
\hline
\end{tabular}

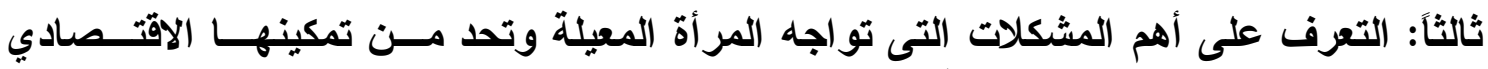
والاجتماعي بريف المحافظة.

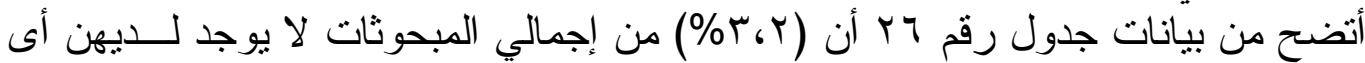

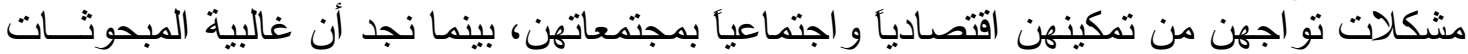

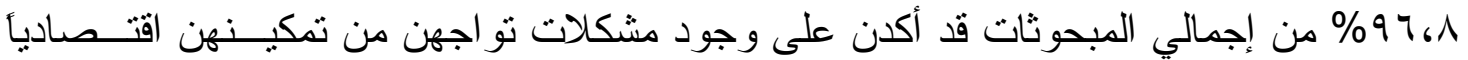

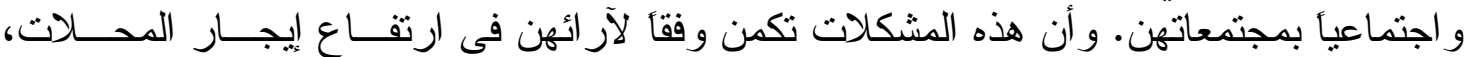

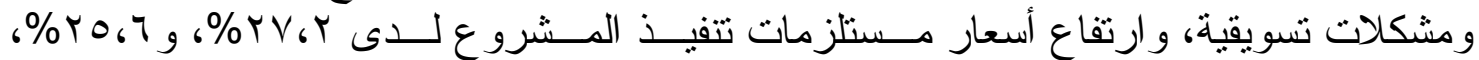

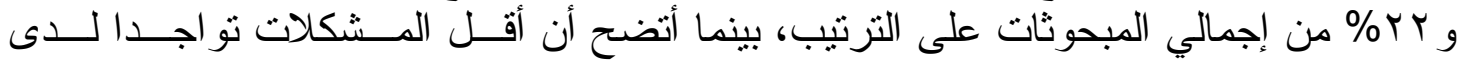




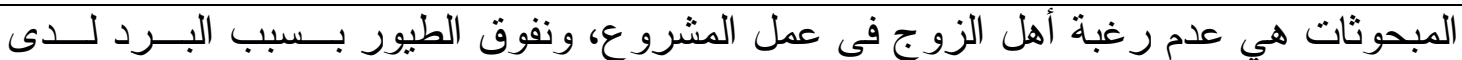

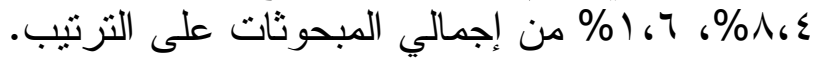

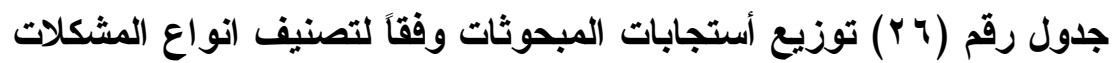

\begin{tabular}{|c|c|c|}
\hline$\%$ & عدد & المشكلات \\
\hline Tr. & $\Lambda$ & لا يوجد مشكلات \\
\hline rVG & $7 \wedge$ & ارتفاع ايجار المحلات \\
\hline Y0.7 & $7 \leq$ & مشكلآت تسويق \\
\hline$r_{6} \cdot$ & 00 & ارتفاع أسعار مستلزمات تتفيذ المشروع \\
\hline$M_{6}$ & $r \cdot$ & المكان غير مناسب لعمل المشروع \\
\hline$\Lambda_{6} \varepsilon$ & Y) & عدم رغبة أهل الزوج في عمل المشروع \\
\hline 167 & $\varepsilon$ & نفوق الطيور بسبب البرد" \\
\hline $1 \cdots 6$ & ro. & المجموع \\
\hline
\end{tabular}

\section{وتوصل البحث للنتائج الاتية:}

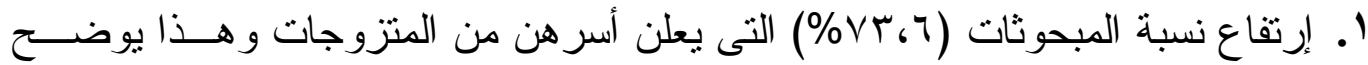

مدى الحاجه إلى محاولة البحث عن فرص عمل من خلال إقامة مشرو عات ممولة من القروض بصفة عامة.

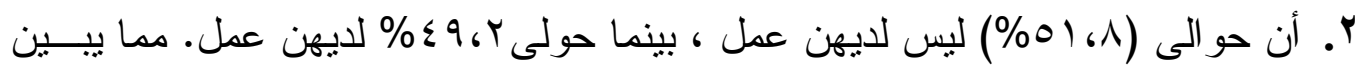

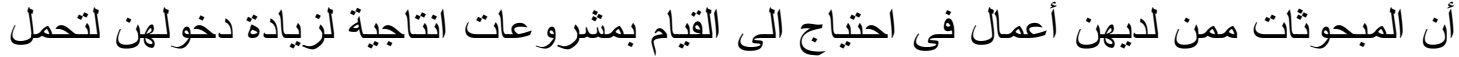
أعباء ومشنقة الحياة.

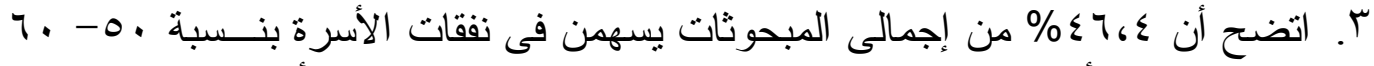

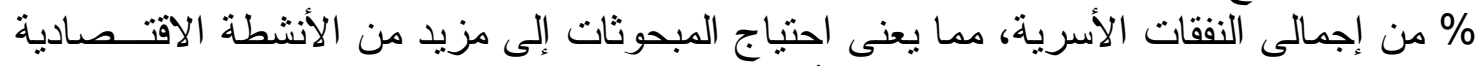

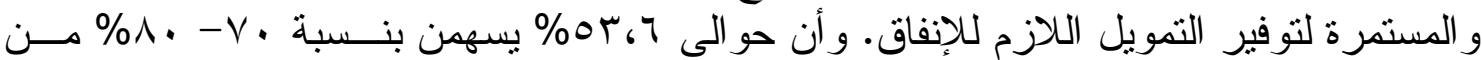

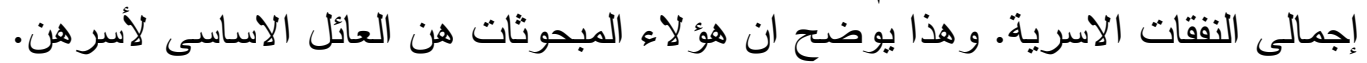

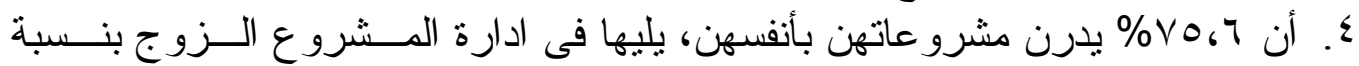

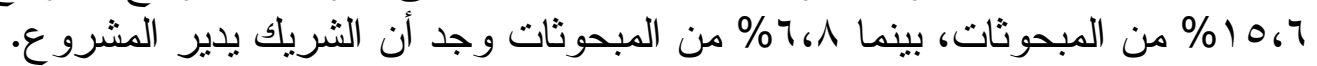

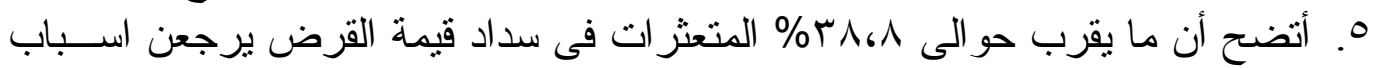

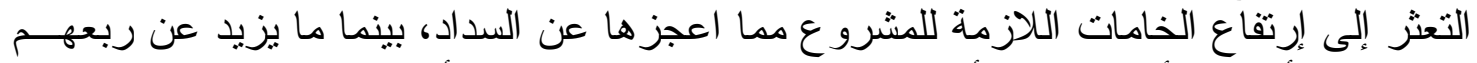

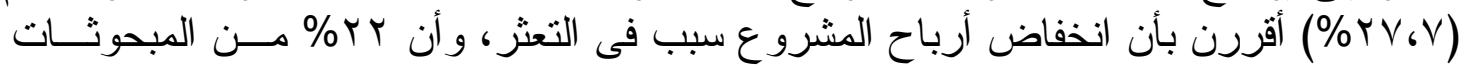

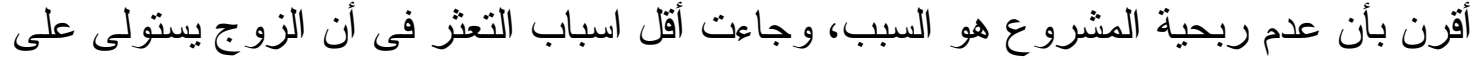

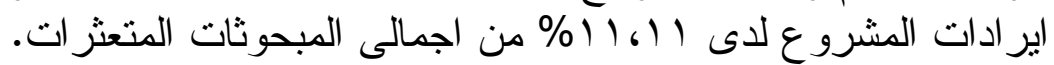

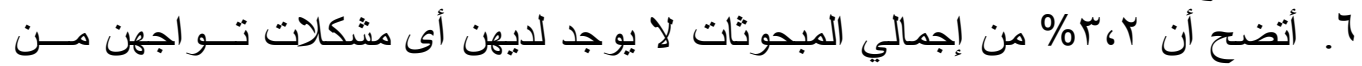

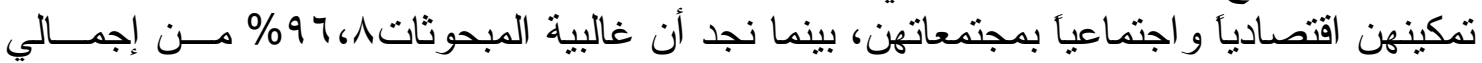
المبحوثات قد أكدن على وجود مشكلات تو اجهن من تمكينهن اقتصادياً و اجتماعياً بمجتمعاتهن.

المر اجع

ا ـ الجهاز المركزى للتعبئة العامة و الإحصاء (1 . . ب). المر أة و الرجل فى مصر ، بيانات منشورة.

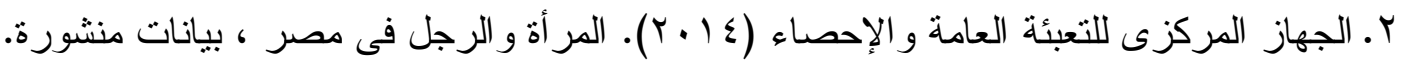

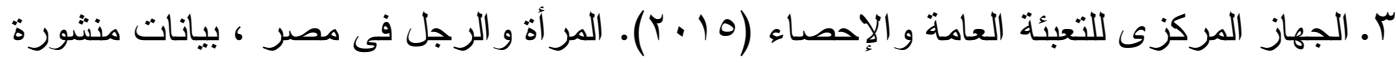

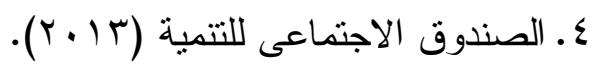




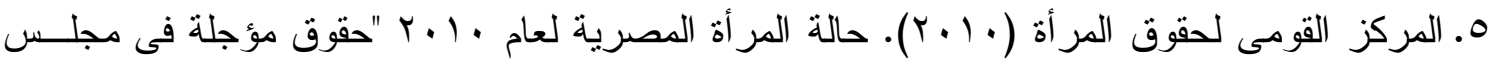

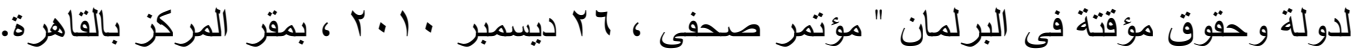

\title{
Socio-Economic Empowerment of Breadwinners Women in Rural Assiut Governorate
}

Moustafa H. Ghanem ${ }^{1}$; Gamal El-Din Rashed ${ }^{1}$; Effat A. El Hamed ${ }^{2}$ and Soha Ibrahem Mohamed Ali Awad ${ }^{1}$

${ }^{1}$ Rural Sociology, Faculty of Agriculture, Assiut University.

${ }^{2}$ Agricultural Extension and Rural Development Research Institute, A.R.C.

\begin{abstract}
The research aimed at identifying economic and social procedure submitted to breadwinners women in Rural Assiut Governorate, from economic loans and projects her own. And identify the most important problems Which facing breadwinners women during the implementation of these projects.

The research was conducted in four cities was Randomly selected from Assiut Governorate its Deirout, Abuteg, El Fath, Assyout, The random selection was made for only one village from each of the four selected cities.

Data were collected from 250 breadwinners Women selected randomly from four villages in Assiut Governorate, by personal interview using a questionnaire, frequencies, percentages were used for data processing and analysis using Excel and SPSS programs, and data were collected during December 2016 and January 2017.

Results show that High percentage of respondents $73.6 \%$ Announces their families They are married, and About 3.2\% of the total respondents they don't have any problems, while $96.8 \%$ of the total respondents they have problems at economic and social empowerment.
\end{abstract}

